\title{
Optimization of Vineyard Water Management: Challenges, Strategies, and Perspectives
}

\author{
José Manuel Mirás-Avalos ${ }^{1, * \mathbb{D}}$ and Emily Silva Araujo ${ }^{2,+}$ (D) \\ 1 Unidad de Suelos y Riegos (asociada a EEAD-CSIC), Centro de Investigación y Tecnología Agroalimentaria \\ de Aragón (CITA), Av. Montañana, 930, 50059 Zaragoza, Spain \\ 2 Laboratory of Entomology Professor Ângelo Moreira da Costa Lima, Department of Basic Pathology, Federal \\ University of Paraná, Av. Cel. Francisco H. dos Santos, s/n, Curitiba 81531-980, Paraná, Brazil; \\ araujosemily@gmail.com \\ * Correspondence: jmmiras@cita-aragon.es \\ + Current address: Unidad de Recursos Forestales, Centro de Investigación y Tecnología Agroalimentaria de \\ Aragón (CITA), Av. Montañana, 930, 50059 Zaragoza, Spain.
}

check for

updates

Citation: Mirás-Avalos, J.M.; Araujo, E.S. Optimization of Vineyard Water Management: Challenges, Strategies, and Perspectives. Water 2021, 13, 746 https://doi.org/10.3390/w13060746

Academic Editor: Julio Berbel

Received: 3 February 2021

Accepted: 8 March 2021

Published: 10 March 2021

Publisher's Note: MDPI stays neutral with regard to jurisdictional claims in published maps and institutional affiliations.

Copyright: (c) 2021 by the authors. Licensee MDPI, Basel, Switzerland. This article is an open access article distributed under the terms and conditions of the Creative Commons Attribution (CC BY) license (https:// creativecommons.org/licenses/by/ $4.0 /)$.

\begin{abstract}
Water availability is endangering the production, quality, and economic viability of growing wine grapes worldwide. Climate change projections reveal warming and drying trends for the upcoming decades, constraining the sustainability of viticulture. In this context, a great research effort over the last years has been devoted to understanding the effects of water stress on grapevine performance. Moreover, irrigation scheduling and other management practices have been tested in order to alleviate the deleterious effects of water stress on wine production. The current manuscript provides a comprehensive overview of the advances in the research on optimizing water management in vineyards, including the use of novel technologies (modeling, remote sensing). In addition, methods for assessing vine water status are summarized. Moreover, the manuscript will focus on the interactions between grapevine water status and biotic stressors. Finally, future perspectives for research are provided. These include the performance of multifactorial studies accounting for the interrelations between water availability and other stressors, the development of a cost-effective and easy-to-use tool for assessing vine water status, and the study of less-known cultivars under different soil and climate conditions.
\end{abstract}

Keywords: climate change; drought; irrigation; remote sensing; Vitis vinifera (L.); wine

\section{Introduction}

Grapevine (Vitis vinifera L.) is a perennial crop grown worldwide (Figure 1). According to data from the latest report on world viticulture issued by the Organisation Internationale de la Vigne et du Vin (OIV), the world surface devoted to grapevine cultivation reached, approximately, 7.4 million ha in 2018, with a total wine production of 292 million hL [1]. Five countries encompassed half of this surface: Spain, China, France, Italy, and Turkey. However, $50 \%$ of the world wine production is concentrated in three countries: Italy, France, and Spain [1]. From the same report, it can be gathered that although the world vineyard area underwent a slight downward trend over the last few years, the global grape production experienced a noticeable upward trend over the last two decades, wine grapes accounting for $57 \%$ of the total grape production [1]. In fact, wine trade in monetary value has been increasing continuously, reaching a record-breaking value of approximately 30,000 million euros in 2018 [1], revealing the high economic, environmental, and cultural importance of vineyards around the world.

Several factors intervene in grapevine growth and development, and consequently on yield and grape composition, of which weather, soil, and cultural practices are the most important among them [2-5]. Indeed, soil is a key component for wine production, since it provides water and nutrients to the vines as well as determines how the root system is 
implanted and the depth to which roots grow [3]. Soil variability in space and time and soilclimate interactions are the main drivers for vineyard performance on a large scale [6-8], while human effects, such as short-term agricultural practices, can significantly modify soil properties and variability at the vineyard scale $[5,9,10]$. Recent studies proved that landscape organization and topography have a significant impact on the distribution of soil water content at the catchment scale [11]. At the plantation scale, it has been proven that vine water status is variable within the vineyard according to topography, management practices, and soil properties, leading to within-vineyard variability in yield, sugar, and phenolic compounds [12]. In addition, atmospheric conditions exert a control on grapevine growth and development, while climate in interaction with soil controls the distribution of grapevine varieties and the viticultural suitability of a particular location $[13,14]$. It is widely acknowledged that weather factors such as temperature, solar radiation, and water availability strongly influence grapevine growth and development, impacting ultimately on yield and wine quality [3,4]. For instance, radiation and precipitation variability caused by orography influences the soil water content distribution [11], as well as the growth responses of vegetation [15]. A comprehensive description of the roles of these weather variables can be found elsewhere [16]. However, the current manuscript focuses on the water issue, which has been identified as the most relevant resource for the sustainability of viticulture [16-19].

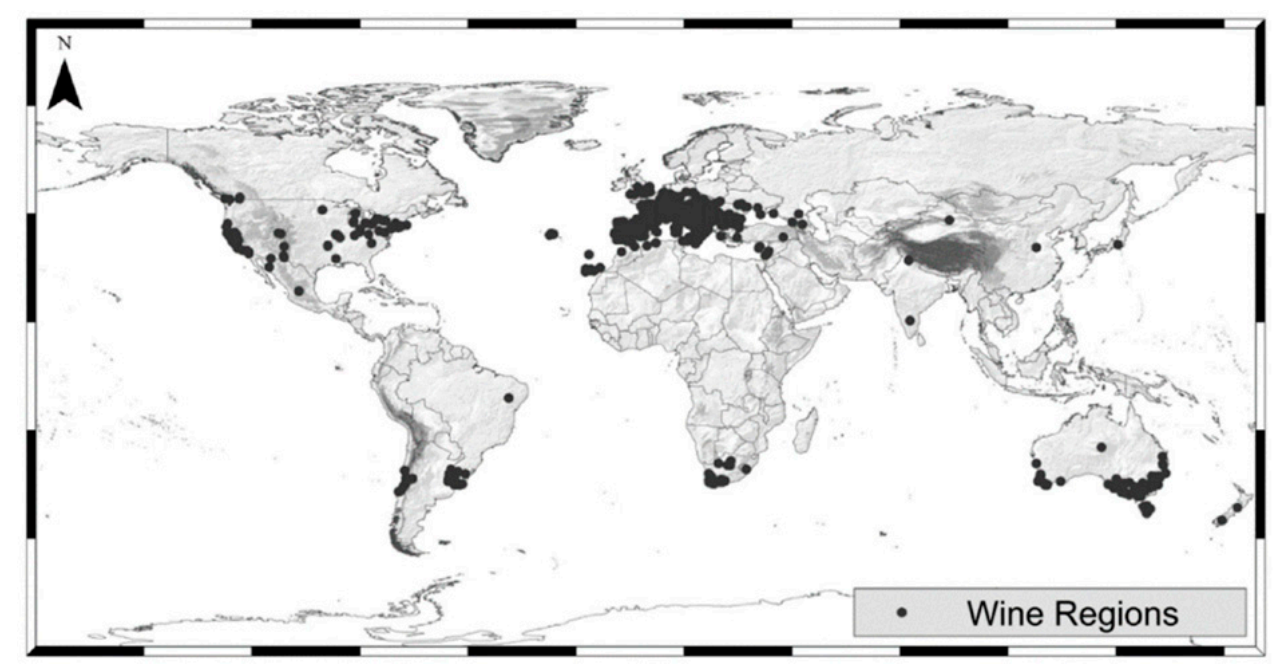

Figure 1. Distribution of wine-growing regions (circles) worldwide (Adapted with permission from ref. [16]. Copyright 2020 the authors).

Water availability has been hindered by climate change, which has impacted viticulture in the last decades, as a consequence of rising temperatures, modifications in precipitation patterns, and an increase in the frequency of extreme events, such as droughts and heat waves [16,18-20]. Although grapevine is a drought-tolerant species, high water requirements are necessary to complete its growth cycle, which coincides with the driest months [21]. Therefore, a more efficient use of water is required for achieving sustainability in viticulture [22-24]. This optimal use of water is possible in the short term through a number of cultural practices, including regulated deficit irrigation and soil management. In addition, rootstocks might play an essential role in improving water-use efficiency (WUE) in the long term because extensive and deeper root systems provide access to a potentially greater water supply $[17,25]$. Recently, several global assessments and reviews dealing with the adaptation needs to be undertaken in vineyards under a global change scenario have been published $[16,19,26]$; however, a holistic approach to the subject of optimization of water management in vineyards has not been addressed since the early 2000s [3], although related subjects such as irrigation $[27,28]$ and changes of vine and berry physiology due to water stress $[29,30]$ have been currently addressed. However, water use by irrigation 
can compromise the environmental sustainability of the crop and be a competition with other critical human uses [22-24]. Moreover, water availability is predicted to decrease because of climate change [20], so irrigation might not be allowed or severely restricted in the future.

In this context, this review aims to evaluate the state-of-the-art on the use of water in vineyards that will provide a framework for making guided decisions and optimize water management in vineyards, leading to the sustainability of viticulture. First, the effects of water stress on vegetative growth, yield, and grape quality will be briefly described (Section 2), followed by an overview of the interactions of water with other biotic and abiotic stressors that can modify grapevine response (Section 3). Second, the main tools for assessing grapevine water status will be described (Section 4). Then, short and long-term management practices for maximizing water use efficiency in vineyards will be presented (Section 5), with a special focus on irrigation (Section 6) and new technologies (Section 7). Finally, some conclusions and perspectives will be provided (Section 8).

Since the current review has a wide-ranging scope, a comprehensive compilation of all previous studies is not feasible. Therefore, the main goal of the current work is to provide an updated overview of the topic of vineyard water management on the basis of relevant and illustrative research, which may be useful not only for academics and researchers but also for stakeholders and decision-makers.

\section{Effects of Water Availability on Vegetative Growth, Yield, and Grape Quality}

Rainfall is a key weather variable in viticulture because it has a large footprint on soil water availability for the grapevines and, consequently, their corresponding water status $[2,16]$. In general, water stress leads to a wide range of effects, but these depend on grapevine developmental stage $[3,16]$. In this section, a brief description of some of these effects will be given.

The induction of inflorescences and floral differentiation occur during bud-break to fruit-set, in two consecutive seasons; hence, enough water availability during this period is critical for achieving significant yields in two harvests [31,32]. Water stress during this developmental stage can cause reductions in shoot growth, poor flower development, and low berry set [33]. In contrast, excessive water availability during this early period in the grapevine growing cycle may overstimulate vegetative growth, which can lead to excessively vigorous and dense canopies, increasing the risk of fungal diseases [34]. Large canopies would extract water quicker in late spring-summer, resulting in water scarcity during that period; all this can be controlled through green pruning. From flowering to berry ripening, severe water stress causes reductions in leaf surface, limiting photosynthesis and promoting flower abortion and cluster abscission [32]. During maturation, dry weather generally favors the production of high-quality wines [35,36]. In contrast, excessive rainfall amounts are commonly detrimental for berry maturation due to sugar dilution and bunch rot incidence [34,37]. Finally, a recent study assessed the consequences of reduced rainfall during dormancy on vine growth in a Shiraz vineyard, indicating that reduced soil moisture in spring delayed the time of budburst, while refilling the soil profile in spring after dry winters favored growth partitioning toward canopy and roots, increased carbohydrate reserves in the trunk, but reduced yield [38].

A great research effort has been devoted to assess the effects of grapevine water status on berry and wine composition, mainly on red varieties under semi-arid environments [3945], although recent studies dealt with white varieties [46-48]. In general, these studies proved that the timing and intensity of water deficits affected the magnitude of the changes in berry metabolism and in wine color, aroma, and flavor by altering berry size and/or the synthesis of berry compounds. Usually, water deficit increases the skin to pulp ratio in the berries, thus increasing the amounts of skin tannins and anthocyanins [49]; however, this depends on other factors such as crop load and defoliation [50]. A meta-analysis proved that for red grapevine cultivars, water status was positively correlated to berry size, total acidity, and malic acid concentration, while it was negatively related to total soluble 
solids [51]. Moreover, this study detected significant relations between vine water status and several wine parameters, such as $\mathrm{pH}$, tartaric acid, anthocyanins, and polyphenols [51]. Furthermore, drought-induced compositional changes to the grapes were transferred to the wines, with an increase in polyphenols and volatile organic compounds [52]. However, these authors observed that the timing and the duration of the water stress in the field only impacted the final wine composition when the severe water deficit started early (at approximately 40 days after flowering) and lasted over the entire season until harvest [52].

\section{Interactions of Vine Water Status with Other Abiotic and Biotic Stressors}

Plant responses to water scarcity are complex and involve adaptive changes and/or deleterious effects [53]. In addition, many factors can influence vine response to water stress, including genotypes, climate, soil, and vineyard management $[17,54]$. Consequently, grapevine responses to water stress can be synergistically or antagonistically modified by the superimposition of other stresses under field conditions. These responses are related to physiological and molecular alterations, including stomatal closure, reduction in photosynthetic rates, modifications of carbohydrate metabolism, hormonal regulation, etc. [29,55-57]. This section provides a summary of the main interactions of water with other stressors and their consequences on grapevine response; for comprehensive descriptions, readers are referred to several reviews focused on this subject $[29,56]$.

Grapevine response to the main abiotic stressors, including extreme temperatures, high solar radiation, and salt contents in the soil has been described in a considerable number of works $[19,58]$. However, the joint effects of water availability and these other stressors have rarely been reported. The grapevine response to combined abiotic and biotic stresses is complex and cannot be inferred from the response to each individual stress [59]. Several factors might impact the response and the recovery of the grapevine, such as the intensity, duration, and timing of the stresses. Moreover, the nature of the pathogens, and the host (rootstock, cultivar, and clone), has a paramount relevance [59].

The impact of heat and water stresses on grapevine was reviewed in detail by Songy et al. [59], showing their strong impact on the initiation and progression of grapevine trunk diseases (GTDs). The term GTDs accounts for a large number of diseases, such as Esca disease, Eutypa dieback, Petri disease, Black foot disease, or Phomopsis dieback. All of them are associated with attacks of several fungi to grapevine perennial organs, which may lead to vine death [60]. External symptoms of GTDs are inconsistent in incidence and prevalence among years, suggesting that abiotic factors might be involved in triggering these diseases, especially in the case of foliar symptoms [61]. It is possible to classify the biotic and abiotic factors affecting GTD symptom expression into three groups: predisposing (e.g., environment, genotype, age, and soil quality), contributing (e.g., pathogens), and inciting (e.g., drought and frost) [62]. High water availability might favor the production of fungal toxins and facilitate their transport throughout the vines during spring as the sap flow resumes [63]. Further research is ongoing to elucidate the mechanisms by which weather variables (temperature, humidity, and rainfall) act as triggers for these diseases.

Another relevant fungal disease in vineyards is bunch rot, caused by Botrytis cinerea, which is considered one of the most important limitations for the wine industry in humid regions $[64,65]$. Infection triggering is affected by berry sugar concentration, cluster compaction, senescing tissues, physical damage, and microclimatic conditions. For instance, in Uruguay, with fertile soils and high precipitation rates, excessive vine vegetative growth is frequent, leading to a high risk of bunch rot infections. Recently, researchers have studied the use of under-trellis cover crops to limit water availability and reduce vine growth and, consequently, bunch rot incidence [66]. These authors tested under-trellis cover crops (UTCC) in combination with supplemental irrigation and nitrogen input. They verified that bunch rot incidence was significantly reduced by UTCC. Moreover, bunch rot incidence was significantly higher in treatments with nitrogen input even when vegetative growth or canopy density was not affected. Therefore, grapevine nitrogen status could be one factor affecting directly bunch rot susceptibility, but it is not the only one [66]. Previous 
studies suggested that drought stress tolerance in grapevines involves the activation of polyamine oxidation, suggesting an improved immune response and reduced susceptibility to $B$. cinerea $[67,68]$. Furthermore, the incidence and severity of $B$. cinerea were significantly smaller when grapevines suffered from some water restriction [66]. Therefore, seasonal grapevine water status and disease susceptibility at harvest might be directly related.

Water stress does not only affect fungal diseases but also plant-insect interactions. Recently, Del Cid et al. [69] studied how water stress impacts the transmission of Homalodisca vitripennis (Germar) (Hemiptera: Cicadellidae). This insect species is a vector of the xylem-limited bacterium Xyllela fastidiosa, which causes Pierce's disease of grapevine and several other diseases in a wide range of economically important crops [70]. Insect vectors, which include numerous species of xylem sap feeders, are the unique way of natural plant-to-plant transmission of X. fastidiosa; the bacteria persistently colonize the vector mouthparts, and there is no latent period required for transmission. It was verified that the acquisition of $X$. fastidiosa by $H$. vitripennis was more efficient under water stress. However, when vectors had a choice of an uninfected well-watered grapevine versus an infected water-stressed grapevine, transmission efficiency declined as water stress levels increased [69]. Pairing an infected water-stressed vine together with a healthy well-watered vine resulted in a reduced transmission of $X$. fastidiosa, indicating that vectors strongly preferred to settle and feed on healthy well-watered vines, which was likely due to an unsuitable xylem sap tension for ingestion due to water stress [71]. Therefore, Del Cid et al. [69] proposed that vector-plant and pathogen-plant, but not vector-pathogen, interactions were impacted by water stress. The above-mentioned examples suggest that multifactorial studies are needed to fully elucidate how several stressors affect jointly grapevine performance.

\section{Methods for Determining Vineyard Water Status: Advantages and Drawbacks}

In order to optimize water management in vineyards, an accurate estimation of the grapevine water status is required. In this context, several methods are currently available for obtaining a measure of grapevine water status and water-use efficiency, which can be determined at different scales (Figure 2). This section aims to provide a brief overview of some of the most common techniques for assessing grapevine water status, while giving their main advantages and drawbacks. For a comprehensive review of these methods, readers may refer to the excellent articles published by Fernández [72] and Rienth and Scholasch [73]. For organizational purposes, the methods will be divided into indirect and direct (plant-based) approaches. It must be noted that models and remote sensing techniques have been excluded because they require their own section. 


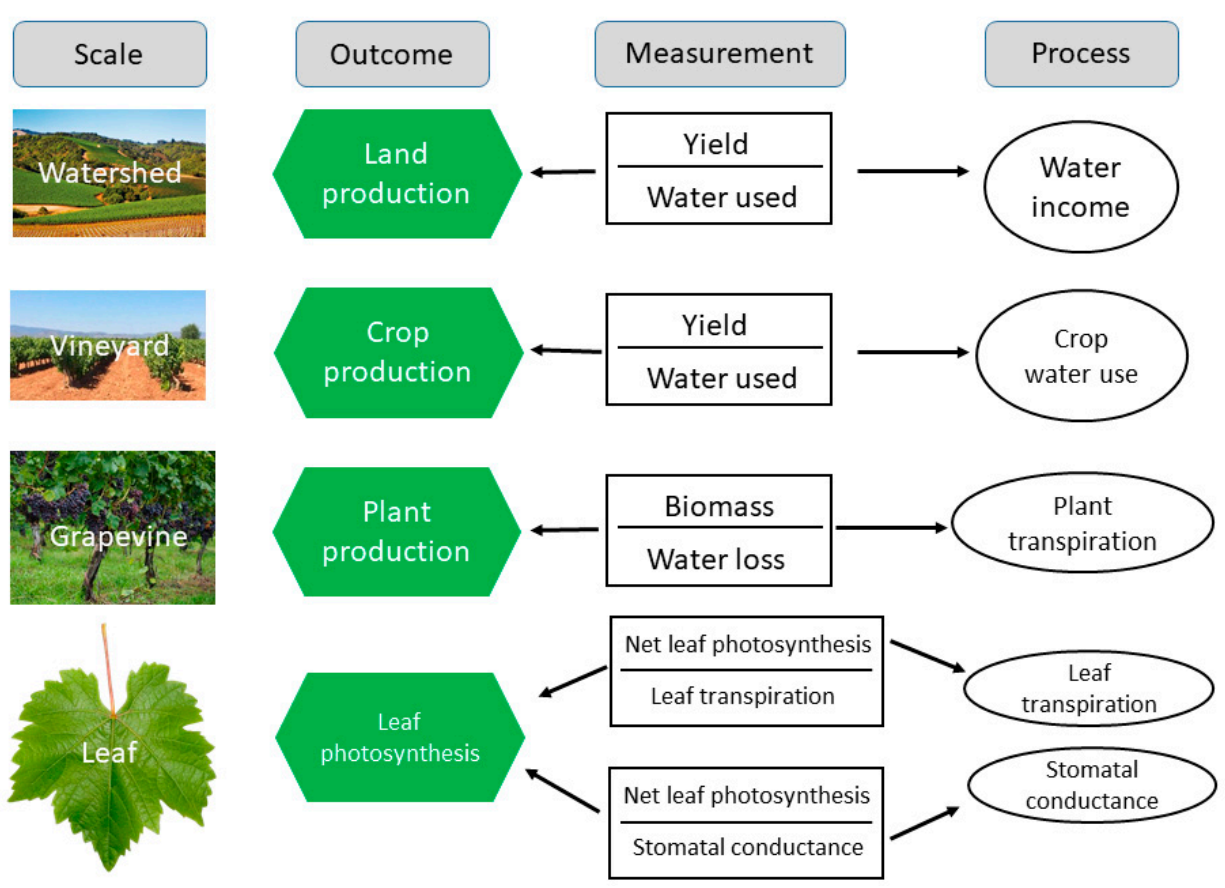

Figure 2. Measurement of the grapevine water-use efficiency at different scales, from the leaf to the watershed level (Adapted with permission from ref. [17]. Copyright 2015 INRA and Springer-Verlag France).

\subsection{Indirect Methods}

\subsubsection{Soil-Based Methods}

These approaches directly determine either soil water content (water percentage in a given volume of soil) or soil water potential (physical force holding water in the soil). A great number of different sensors is available, some reading water suction directly and most using indirect measurements via electric currents. Soil moisture sensors use different soil physical, chemical, and mechanical properties to obtain data of several types including electrical, electromagnetic, optical, radiometric, mechanical, acoustic, pneumatic, or electrochemical measurements. The functioning of soil moisture sensors and their characteristics are well described, and their assets and drawbacks of their operation are well-known $[74,75]$.

In the case of field crops and vegetables, soil moisture sensors have been widely accepted as tools for estimating crop water needs and providing a reliable criterion for water management techniques including irrigation scheduling and the management of cover crops [76]. However, in the case of fruit orchards and vineyards, soil moisture sensors present several disadvantages related to the heterogeneity of the soil within the orchard or vineyard as well as different soil water motion patterns resulting from the adoption of several management practices such as deficit irrigation strategies [77], alternating the use of cover crops and minimal tilling. This leads to the need for installing several probes, which makes the management of the information difficult [78]. Moreover, there is a lack of thresholds of soil moisture to determine whether a vineyard is suffering from water stress and to which extent [79]. Accuracy and correct placement are relevant characteristics, as they affect the ability of soil moisture sensors to provide a reliable estimate of vine water status $[75,80]$. Indeed, the fact that once installed, these sensors cannot be moved causes soil moisture to be only measured on a small portion of the vineyard. Furthermore, vine deep rooting limits the possibilities of soil-based methods.

Several authors related measurements of soil water content, mainly using capacitance sensors (Figure 3), with plant-based indicators of grapevine water stress in order to obtain thresholds for efficient water management $[79,81]$. In a Thompson Seedless vineyard located in San Joaquin Valley (California, USA), Williams and Trout [79] were able to detect 
strong correlations between soil water content (and matric potential) and grapevine leaf and stem water potentials, which allow them to obtain thresholds of these plant-based indicators at 50\% depletion of plant available water in the soil that could be used for designing irrigation strategies and other practices such as the mowing of cover crops. In contrast, Intrigliolo and Castel [81], working on a Tempranillo vineyard in Requena (Valencia, Spain), did not observe a clear relation between soil and plant-based measurements, which was likely due to the high spatial variability of soil water content. In an Albariño vineyard located in Pontevedra (Galicia, Spain), weak correlations were detected between soil water content and vine leaf water potential, although the strength of these correlations depended on the irrigation treatment imposed [82]. These contrasting results highlight the limitations of this methodology and the difficulty of extrapolating vine water status from soil moisture measurements [54]. Nevertheless, current research aimed at automating drip irrigation has successfully used soil moisture sensors for tuning the estimations provided by soil water balance algorithms, showing the feasibility of this approach in several situations including plum [83], apple [84], citrus [85], and hedgerow olive orchards [86]. However, this promising approach has not been applied to vineyards yet, although promising attempts have been recently reported [87]. In this context, research has been focused on the combined use of thermal images and co-registration algorithms to improve the estimation of the crop water stress index and, consequently, improve water management [88].
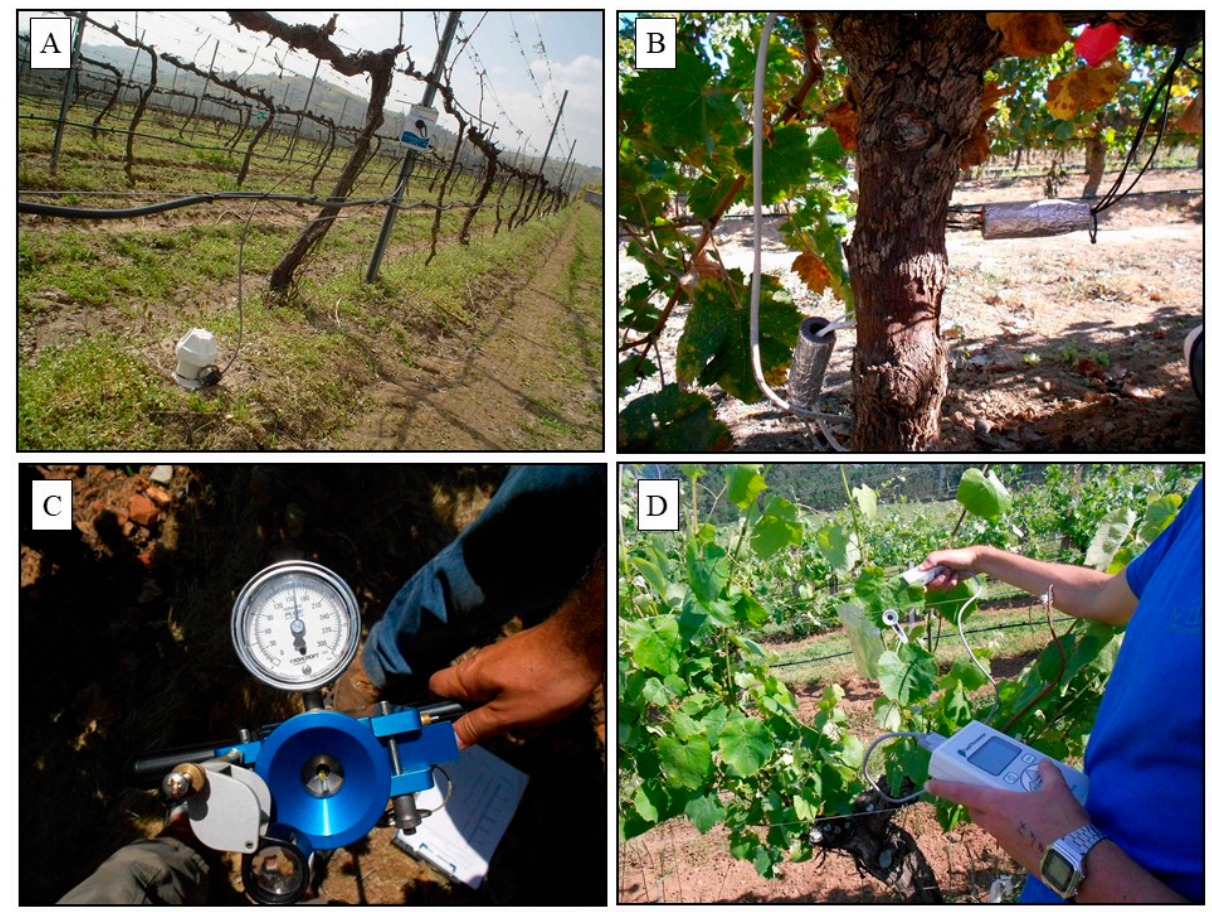

Figure 3. Devices for the assessment of grapevine water status: (A) Soil capacitance probe for continuous monitoring of soil water content; (B) Sap flow probe in the trunk of a grapevine; (C) Pressure chamber; (D) Hand-held porometer for determining stomatal conductance. Photos were taken by J.M. Mirás-Avalos.

\subsubsection{Atmosphere-Based Methods}

Grapevine evapotranspiration (ET) can be assessed using atmospheric measurements within the vineyard. Several techniques are currently available for assessing ET without separation between soil evaporation and vine transpiration, including the eddy covariance method and the Bowen ratio energy balance method [89,90]. Eddy covariance is the standard method for determining energy and substance fluxes. It measures directly carbon, water, and heat flow between plant communities and the atmosphere [89]. The Bowen ratio energy balance method has been used to estimate vineyard ET over the whole growing 
season, proving reliable in arid regions [90]. However, these techniques have several drawbacks including the high cost of the sensors and the need for large extensions in the case of eddy covariance, which make them unsuitable for water management purposes, and they are still restricted to research [91].

\subsection{Direct (Plant-Based) Methods}

\subsubsection{Visual Observations}

Considering that vegetative growth slows down as an early response to water deficit, observing the apical meristem or apex of vines is the simplest way to assess vine water status. This can be performed systematically by observing 30-50 apexes per plot and classifying them into three categories: (i) a growing apex, where the first expanded leaf is small and well beneath the apex; (ii) the first expanded leaf covering the apex; and (iii) the apex having dropped and shoot growth having completely ceased [92]. However, this method presents several drawbacks including its low sensitivity to moderate water stress and the high cost in personnel for covering large extensions. Tendrils could be an earlier indicator, as they expand beyond the shoot tips in the absence of water stress, but a moderate water deficit causes their wilting and subsequent abscission when the stress becomes severe [93].

\subsubsection{Grapevine Water Potential}

Water potential $(\Psi)$ is the suction pressure that a plant needs to extract water from the soil. When the amount of soil water available decreases, plant $\Psi$ would also decrease. Therefore, $\Psi$ is a reliable indicator of the water stress experienced by grapevines.

Since its development in the 1960s [94], the pressure chamber (Figure 3) is one of the most used methods for determining $\Psi$ in grapevines $[79,95]$ due to its flexibility, accuracy, and relative quickness [94]. However, some discrepancies exist about how and when these measurements should be carried out [96]. Indeed, the pressure chamber method can provide several modalities of $\Psi$, including predawn, leaf, and stem water potentials. However, it must be considered that there is still disagreement on how leaf samples should be collected for performing these measurements [97]. Recently, it has been established that re-cutting the petiole has no effect on $\Psi$ values [97]. Moreover, it was reported that up to 30 s of time span between sample excision and pressurization was acceptable for accurate $\Psi$ determinations, as long as the sample was kept shaded during that time [97].

Predawn leaf water potential $\left(\Psi_{\mathrm{pd}}\right)$ measures vine water status when the stomata are mostly closed, providing information on the root-zone soil water potential [98]. It is a stable measure and gives reliable indications on vine water status. However, $\Psi_{\text {pd }}$ could be in equilibrium with the most humid soil layer, so the absolute available water content in the soil could be smaller than expected [98]. In addition, $\Psi_{\text {pd }}$ gives an indication of the plant capacity to recover during the night, but not of what happens during the day, when plant hydraulic conductivity can limit water transport to the leaves hampering water status maintenance and forcing reductions in stomatal conductance that result in reduced photosynthesis and higher leaf temperature. In the case of isohydric-behaving varieties [99], this modality provided satisfactory discrimination of vines under different deficit irrigation strategies [100]. It must be noted that nighttime stomatal closure is being questioned nowadays, as recent studies indicated that several grapevine varieties differed on the level of stomatal closure at night, which might have implications on $\Psi_{\text {pd }}$ values [101]. Moreover, $\Psi_{\text {pd }}$ reflects long-term evolutions and, as a consequence, might be preferred for other water management practices apart from irrigation.

Leaf water potential ( $\Psi_{\text {leaf }}$ ) is usually measured at mid-morning or at noon, when the evaporative demand is maximum; consequently, these values are affected by the predominant environmental conditions (vapor pressure deficit, soil water availability, solar radiation, temperature, etc.) at the time of measurement. Therefore, $\Psi_{\text {leaf }}$ values are not preferred for their use in irrigation scheduling [96] or other practices that require modulating water management in the vineyard. Nevertheless, this modality of $\Psi$ has 
been successfully used for scheduling irrigation in experimental vineyards and thresholds depending on the developmental stage of the vines have been defined [102].

Finally, stem water potential $\left(\Psi_{\text {stem }}\right)$ is measured on non-transpiring leaves, namely leaves that have been bagged in opaque and hermetic bags $1-2 \mathrm{~h}$ prior to measurement [95], although $10 \mathrm{~min}$ have been recently reported as sufficient [97]. Therefore, $\Psi_{\text {stem }}$ has a lower variability than $\Psi_{\text {leaf }}$ because of the influence of leaf position on the latter modality, and it provides a reliable indicator of the capacity of the grapevine to conduct water from the soil to the atmosphere, so it can be used as a tool for irrigation scheduling $[95,96]$.

These three modalities have been successfully employed to determine grapevine water status and provide useful information for water management in the vineyard, although previous reports showed contrasting observations. For instance, some reports indicate

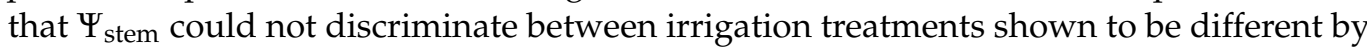
$\Psi_{p d}[81,100]$. Other studies suggested that early- or mid-morning $\Psi_{\text {leaf }}$ measurements are more suitable because differences in water status become maximum, as well as the discrimination among irrigation treatments [103]. A great corpus of research suggests that $\Psi_{\text {stem }}$ is the most adequate modality of water potential due to its capacity for discriminating among irrigation treatments, its sensitivity, and its stability $[79,95,96]$. A recent metaanalysis comprising more than 70,000 measurements of $\Psi$ performed under different environmental conditions in Spain concluded that $\Psi_{\mathrm{pd}}$ and $\Psi_{\text {stem }}$ should be prioritized against $\Psi_{\text {leaf }}$ for the assessment of grapevine water status [96]. Nevertheless, since $\Psi$ modalities are strongly correlated, some authors indicate that all of them are valid for assessing grapevine water status [104,105]. In this sense, from a practical standpoint, Ojeda [106] suggested a methodology for managing irrigation of vineyards accounting for thresholds of $\Psi$ in its different modalities, the developmental stage of the vines, and the type of wine to be produced.

Interestingly, some authors suggested the use of water activity meters (psychrometers) for determining leaf water potential in any of its modalities $\left(\Psi_{\mathrm{pd}}, \Psi_{\text {leaf }}\right.$, and $\left.\Psi_{\text {stem }}\right)$ [107]. However, this equipment is usually employed for assessing soil water potential and permanent wilting point [108] and, consequently, a calibration is required for obtaining reliable measurements. In the case of grapevines, a calibration between measurements with the pressure chamber and a water activity meter has been reported [109]. The average difference between measurements with both methods was established in $-0.43 \mathrm{MPa}$ [109]. Later, this equipment was used for monitoring grapevine (cv. 'Albariño') water status over four years and proved useful for discriminating among irrigation treatments [82]. Despite these promising results, the workload and time needed to perform measurements with the water activity meter as well as the fact that the obtained values are more negative than those commonly used for water stress classification [110] may restrict the use of this technique for making decisions about vineyard water management.

Finally, several authors have proposed thresholds for classifying the measured water potential into water stress levels $[106,110]$. These levels allow for developing an efficient management of vineyard water management in accordance with the phenological stage of the grapevines and the wine type to produce [106]. Table 1 details the values commonly accepted as thresholds for all the leaf water potential modalities commented in this section.

Table 1. Water potential values $(\mathrm{MPa})$ with respect to vine water stress thresholds (adapted from $[106,109,110])$.

\begin{tabular}{ccccc}
\hline Water Stress Level & $\boldsymbol{\Psi}_{\mathbf{p d}} \mathbf{1}^{\mathbf{1}}$ & $\boldsymbol{\Psi}_{\text {leaf }}$ & $\boldsymbol{\Psi}_{\text {stem }}$ & WAM \\
\hline No stress & $>-0.2$ & $>-0.9$ & $>-0.6$ & $>-1.27$ \\
Weak or mild & -0.2 to -0.3 & -0.9 to -1.1 & -0.6 to -0.9 & -1.27 to -1.45 \\
Mild to moderate & -0.3 to -0.5 & -1.1 to -1.3 & -0.9 to -1.1 & -1.45 to -1.62 \\
Moderate to severe & -0.5 to -0.8 & -1.3 to -1.6 & -1.1 to -1.4 & -1.62 to -1.88 \\
Severe & $<-0.8$ & $<-1.6$ & $<-1.4$ & $<-1.88$ \\
\hline
\end{tabular}

\footnotetext{
$1 \Psi_{\text {pd }}=$ pre-dawn leaf water potential; $\Psi_{\text {leaf }}=$ midday leaf water potential; $\Psi_{\text {stem }}=$ midday stem water potential; WAM = water activity meter.
} 
A major inconvenience of this technique is the high number of measurements needed for ensuring their representativeness over heterogeneous vineyards, which must be performed by skilled staff, increasing the costs of this technique [97]. Another drawback is the frequency in which these measurements are required over the growing season. Finally, a recent study reported that the water potential observed in a plant is not only a function of the available water in the soil but is also an integrative measure of the interactions among all the elements in the soil-plant-atmosphere continuum [111]. The factors that influence the water potential value include the cultivar, environment, soil type, and the relationships between the canopy and the root system. Any natural or human modification of this latter relationship will induce changes in the water potential value [111]. Therefore, it is recommended to monitor both grapevine water potential and soil water content in order to efficiently schedule irrigation [111]. Finally, the effect of the operator is greater than that of sampling [97], so vineyard technicians must be trained in using the pressure chamber. These constraints restrict the use of the pressure chamber technique in commercial vineyards.

\subsubsection{Carbon Isotope Discrimination}

In the atmosphere, two different stable carbon isotopes are present: ${ }^{12} \mathrm{C}$ predominates over ${ }^{13} \mathrm{C}$ [112]. The enzymes involved in photosynthesis use the former one preferentially [113] through the process of isotope discrimination. Under water stress conditions, this discrimination is less severe, and sugars produced during water-deficit situations contain more ${ }^{13} \mathrm{C}$ than those produced when water is not limiting. Therefore, the carbon isotope ratio $\left(\delta^{13} \mathrm{C}\right)$ of the grape juice is an integrative indicator of the water deficit experienced by vines over grape ripening [114].

This ratio has been related to minimal values of $\Psi_{\mathrm{pd}}$ during grape ripening $[114,115]$ and thresholds have been produced, ranging from -27 (no water stress) to -20 (severe water stress) [114]. Since $\delta^{13} \mathrm{C}$ can only be obtained at the end of the growing season, it is not susceptible to be used for irrigation scheduling or agronomic management. However, it can be valuable for evaluating agronomic practices of past seasons, providing useful information for optimizing future strategies [110]. Moreover, its low cost allows for producing maps of vine water status at the plot [116] or the terroir scale [117]. A recent study proved that $\delta^{13} \mathrm{C}$ can be an inexpensive and simple surrogate for estimating soil available water capacity, leading to a better consideration of the contribution of deeper soil horizons in the case of vineyards [118]. Finally, determining $\delta^{13} \mathrm{C}$ in leaves has been recently demonstrated as a reliable and sensitive indicator of vine water deficit even when the intensity of the water stress was low or moderate [119].

\subsubsection{Leaf Gas Exchange Measurements}

Among the different variables that can be measured through gas exchange in plant leaves, stomatal conductance is the most relevant. This variable is the ease of passage of $\mathrm{CO}_{2}$ or water vapor entering through the stomata [72]. Stomatal conductance is highly informative on plant response to water stress because it changes with atmospheric demand and soil water status. In the case of grapevines, stomatal conductance has been identified as a suitable parameter to detect the degree of water stress [120,121]. These measurements can be made under field conditions using porometers (Figure 3) or infrared gas analyzers. However, these tools are rather expensive and complex to use, requiring frequent calibrations. Moreover, they must be operated manually, limiting the use of stomatal conductance as a water stress indicator. Moreover, leaf gas exchange measurements are subject to several sources of variability including the timing of measurements and the location of the sampled leaf within the grapevine canopy, among others [72]. Another limitation is that stomatal conductance is not always closely related to grapevine water status [122,123]. A recent report on fruit trees proposed a method for estimating stomatal conductance from values of radial sap flux density and air vapor pressure deficit that can be measured automatically [124], which may open the door for the use of stomatal conductance as a 
water stress indicator in commercial fruit orchards. In the case of grapevines, threshold, as well as optimal, values for the different levels of water stress have been defined [73,125].

\subsubsection{Sap Flow, Trunk Diameter, and Leaf Turgor}

Sap flow measurements reflect the flow of water from the soil through the plant (within the xylem tissue) and into the atmosphere through the stomata (whole-plant transpiration) without disturbing the leaf environment [126]. Currently, several methods are available for sap flow measurement, which can be divided in two groups: (i) thermal dissipation [126] and (ii) stem heat balance [127].

Thermal dissipation probes [126] are simpler and more cost-effective than stem heat balance equipment. In both cases, sap flow sensors (Figure 3) are robust and sufficiently reliable for operation in the field over extended periods. Moreover, they can be easily automated and implemented with data transmission systems [72]. However, invasive methods such as the thermal dissipation probes require calibration using specific correction factors [128]. In this sense, the stem heat balance method has been adopted for computing vine transpiration and as practice to drive irrigation strategies [73].

Sap flow measurements have been employed to monitor grapevine water status and could be a reliable option for water management in vineyards [128-130]. However, the heat balance method has been reported to overestimate actual sap flow by 50 to $100 \%$ at high flow rates in mature grapevines [131], while thermal dissipation produced errors within $\pm 10 \%$, and it was considered suited for long-term measurements of total water use [132]. In addition, a high number of probes are usually required, which renders the system costly and time- and labor-consuming [72]. These drawbacks combined with the fact that the user must be trained for the required data processing pose severe limitations to the use of this approach in commercial vineyards.

Temporal patterns of water flow within the trees and grapevines cause stem diameter variations (SDV); the magnitude of these variations depends on stem diameter and wood elasticity [133]. Linear variable displacement transducers (LVDTs) provide continuous measurements of stem and trunk diameter fluctuations (TDFs), which are related to plant growth and water status $[130,134]$. Different water stress indicators can be derived from the resulting daily patterns of SDV [72], including maximum daily shrinkage (MDS) and stem growth rate (SGR), which are the most commonly used in irrigation scheduling and other agronomic practices such as cover crop management and fertilization. However, several factors have a remarkable influence on MDS and SGR, including environmental water conditions and growth patterns, crop load, plant age, and size $[133,135,136]$. In the case of grapevines, the usefulness of MDS as a water stress indicator has been questioned due to its dependence on the phenological period [137]. Moreover, it appears that the use of LVDTs for scheduling irrigation and other water management practices in vineyards would require a specific calibration for different grapevine cultivars [134]. Recently, a study pointed out that the different hydraulic pathways generated by particular training systems can cause a different response of trunk diameter fluctuations [130]. Therefore, expert interpretation of SDV records is required, limiting the potential use of these indicators for automating the calculation of the irrigation dose [72].

Leaf turgor exerts a strong influence on stomatal behavior and, consequently, on plant water status. In fact, leaf turgor has been reported to explain over $87 \%$ of the observed decline in stomatal conductance due to water stress for three woody species: almond, grapevine, and olive [138]. This supports the utility of leaf turgor-related measurements as a valid indicator of water stress [72]. Leaf turgor measurements in the field can be made using the leaf patch-clamp probe that provides a nearly real-time signal that is inversely correlated with leaf turgor pressure [139]. These probes work well in hydrated and moderately hydrated leaves, but at a certain level of dehydration, the pressure clip does not properly sense the turgor pressure [72]. This approach has been tested in grapevines [140], showing its robustness, relative low cost, and suitability for automatic and continuous recording 
under field conditions. Therefore, this system has a great potential for assessing plant water status in vineyards and fruit tree orchards [72].

\section{Management Practices for Maximizing Water-Use Efficiency in Vineyards}

The increasing water deficits occurring due to climate change affect yields negatively and decrease the profitability and sustainability of wine production [19]. Therefore, adaptations to drier growing conditions are becoming increasingly pertinent in viticulture worldwide [19]. Consequently, a huge effort in applied and fundamental research has been focused on the exploration of the capacity to optimize grapevine water use [17]. In this section, we summarize several of the available management practices and adaptations to increased drought aimed at improving water use in vineyards. These include the use of drought-resistant plant material (both rootstocks and scions), soil management (mulching, cover crops), and canopy management, while the use of irrigation, due to its relevance, will be the subject of the next section of this review.

\subsection{Drought-Resistant Plant Material}

Rootstocks are essential in many vineyards since phylloxera reached Europe in the second half of the 19th century. Rootstocks vary considerably in their ability to resist drought $[25,141]$. The choice of more water-use efficient and drought-tolerant rootstocks has been proposed as an adaptation measure to climate change in viticulture [141-143]. The rootstock chosen can modify vineyard adaptation to drought conditions through several physiological mechanisms, as detailed in a recent review [25]. In this sense, the great variability within the genus Vitis can provide a potential genetic resource to improve water-use efficiency in vineyards [17]. Therefore, the use of drought-resistant rootstocks could be an environmentally and cost-effective adaptation measure to increased drought conditions, allowing for sustaining yields and reducing quality losses from excessive water stress [19].

Similarly, grapevine cultivars present a large variability in their tolerance to water stress $[17,144]$, which may be related to the regulation of water potential in response to increasing atmospheric demand and soil water depletion [122]. Moreover, a large variability in water-use efficiency has been reported within the same grapevine cultivar, depending on the experimental conditions $[55,145]$. This variability can be partly explained by the role of rootstocks, which also show different levels of resistance to drought and might provide certain tolerance to water stress to the scion [146]. The changes in carbon discrimination in juice sugars between wet and dry years can allow for characterizing the drought resistance of different grapevine cultivars [19]. In this context, grapevine varieties native from the Mediterranean basin, such as Grenache and Carignan, are considered drought tolerant, while local varieties may have even a higher resistance to water deprivation and could be tested outside their original regions of production $[145,147]$. This large variability in grapevine cultivar response to water restrictions offers an opportunity to select the most appropriate cultivar depending on the environmental conditions.

\subsection{Soil Management}

Soil water-holding capacity has a crucial influence on vine water status, and under dry climates, vineyards should be planted in soils with, at least, a medium water-holding capacity $[11,12,19]$. Management of the water stored in the soil is essential to reduce plant irrigation requirements. Therefore, practices aiming at improving soil physical and chemical structure and properties must be favored. In this sense, reducing direct soil water evaporation by mulching can be a cost-effective strategy to improve water use in vineyards [17]. The advantages of mulching in vineyards have been widely reported, and they include better plant nutrient status, weed control, prevention of soil erosion, and increased yields [148-151]. Organic mulching could also contribute to a circular economy (recycling of pruning residues), increasing soil organic matter content and nutrients, waterholding capacity, and inhibiting weed growth [152,153]. Recently, the short-term effects of 
covering the entire vineyard floor with vine pruning waste on the evapotranspiration of a fully irrigated vineyard have been determined [154]. These authors reported that vineyard water use could be reduced by $16-18 \%$ through the application of this mulching. This moderate decrease in water use could be particularly relevant under rain-fed conditions, when vines experience more severe water stress. A recent study highlighted that water stress integral values over the season were $5 \%$ and $13 \%$ lower in vines on organic mulched soils than in vines on tilled soil under rain-fed and irrigation regimes, respectively [155]. According to these recent studies, combining an organic mulch with no-tillage seems to reduce direct water evaporation from the soil, which eventually caused a better vine water status $[154,155]$. However, the amount of material needed for mulching and its cost of establishment are factors that might restrict the use of pruning waste as organic mulching.

Cover crops can be an alternative vineyard floor management that helps modulate water use in these agro-ecosystems. A cover crop can be purposely seeded or consist of resident species [150]. A number of environmental and agronomical benefits can be obtained from cover crops: soil protection $[149,156]$, improvements in physical and biological properties of soils [157], enhancements in berry quality [158], etc. Table 2 summarizes the main costs and benefits expected under climates with sufficient rainfall amounts and those rain-limited $[17,150]$. In addition, recommended crops for both climate types are included (Table 2). However, the adoption of cover crops as soil management systems in rain-fed vineyards is limited due to the concern of excessive water and nutrient competition between these crops and the vines [150]. In this sense, comprehensive studies have been undertaken to explain the effects of the establishment of a cover crop on the water status of the vineyards $[159,160]$. The findings of these works confirmed the interest of cover cropping for ensuring an improved replenishment of the soil water profile [160]. This is related to a reduction in runoff and the enhancement in water infiltration. Moreover, grapevine root redistribution after the establishment of a cover crop is not only horizontal but also vertical $[160,161]$, proving that a cover-cropped grapevine tends to take up water from deeper soil layers (more than $4 \mathrm{~m}$ deep). Another study proved that the total water use for an entire growing season did not differ between a soil-tilled and cover-cropped vineyards [159]. Recent studies in humid climates also pointed out the benefits of cover crops for reducing excessive vine vigor without compromising yield and berry quality $[162,163]$. In this regard, under-trellis cover crops seem to be a useful tool for reducing vine vigor and improving cluster sunlight exposure in cool humid climates [163]. Under these conditions, vineyard water use can be modulated and improvements in wine sensory attributes have been reported [164]. As mentioned in the section devoted to the interactions between grapevine water status and biotic stressors, cover crops can provide other benefits such as the reduction of the risk of bunch rot infection [59], increase in the number of habitats that can be used for predatory arthropods that can act as natural biological control agents against pests [165], or reduce the expression of GTD symptoms [55]. 
Table 2. Costs and benefits of cover crops for vineyard floor management under climates without water stress and climates with summer droughts (adapted from [17,150]).

\begin{tabular}{|c|c|c|}
\hline & Rain is Not a Limitation & Rain-Limited \\
\hline Costs & $\begin{array}{l}\text { Establishment and regular } \\
\text { maintenance } \\
\text { Irrigation, fertilization, and other } \\
\text { practices must meet the needs of } \\
\text { the grapevines and the cover } \\
\text { crops }\end{array}$ & $\begin{array}{l}\text { Establishment and regular } \\
\text { maintenance } \\
\text { - Competition with vines for water } \\
\text { and nutrients } \\
\text { - Not recommended for early } \\
\text { vineyard establishment }\end{array}$ \\
\hline Benefits & $\begin{array}{l}\text { - Soil protection against erosion and } \\
\text { crusting } \\
\text { Improvement of soil fertility and } \\
\text { structure, increasing soil water } \\
\text { retention capacity } \\
\text { Regulation of vine growth and } \\
\text { yield through a reduction in water } \\
\text { availability to the grapevines }\end{array}$ & 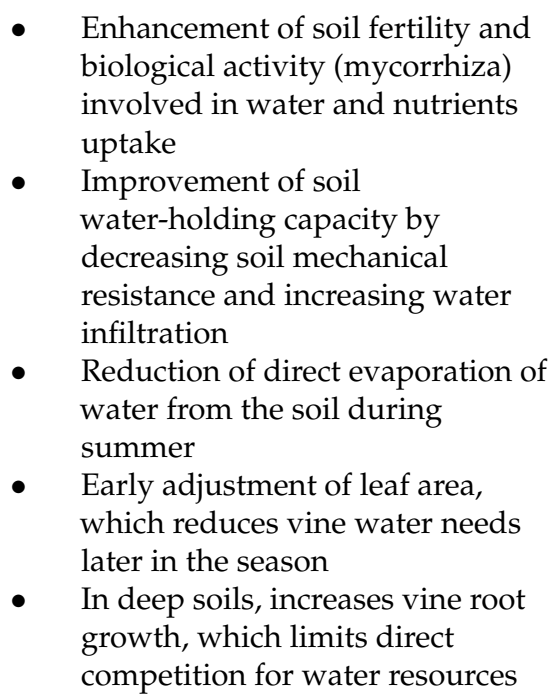 \\
\hline $\begin{array}{l}\text { Recommended } \\
\text { cover crops }\end{array}$ & $\begin{array}{l}\text { Permanent or perennial cover } \\
\text { crops of grasses and/or native } \\
\text { species covering the floor surface } \\
\text { over the grapevine vegetative } \\
\text { growth period } \\
\text { For deep soils with adequate } \\
\text { available water content, the } \\
\text { recommended cover crops include } \\
\text { rapid growing grass species. } \\
\text { (Festuca arundinacea, Lolium } \\
\text { perenne, etc.) }\end{array}$ & 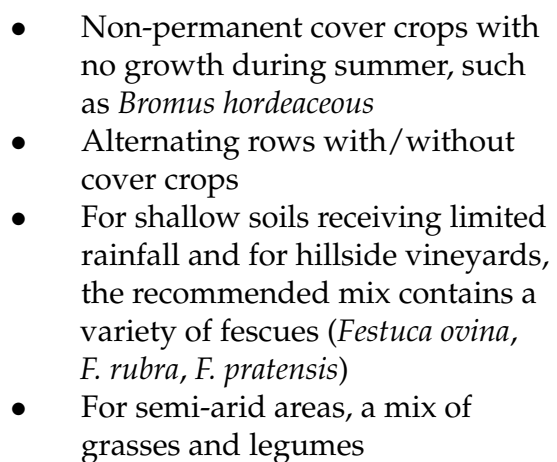 \\
\hline
\end{tabular}

\subsection{Canopy Management}

Canopy management is an important agronomic practice that allows vine growers to regulate the microclimate around the clusters and, consequently, fruit sanitary status, yield, and berry quality. Vine growers in the Mediterranean basin have used a particular training system, the Mediterranean goblet or bush vine, that is resistant to drought (vines can be rain-fed with only $350 \mathrm{~mm}$ of rainfall per year) and high temperatures $[19,166]$. However, the low yields obtained and the difficulty in the mechanization of practices led to the modification of this particular training system.

Training systems evolved toward maximizing the amount of sunlight intercepted and its distribution within the grapevine canopy [167]. In this context, vine row orientation is a factor that exerts large effects on grapevine water use [168]. Grapevines in east-westoriented rows showed higher gas exchange rates at the leaf level than vines in north-southoriented rows, with less negative leaf water potential, suggesting differences in energy balance and physiology induced by row orientation [169]. Recently, Buesa et al. [170] 
observed that orienting vines to the east-west reduced vine transpiration when compared to the north-south orientation $(16 \%$ and $8 \%$ reductions in Bobal and Verdejo cultivars, respectively). Since carbon assimilation was not affected by row orientation, water-use efficiency tended to increase in east-west-oriented vines [170]. These results suggest that under the current scenario of increasing water scarcity, vineyard row orientation will be a key factor when designing new plantations.

Another recent study tested the possibility of enhancing grapevine water-use efficiency by maximizing radiation interception during the mornings but limiting it during the afternoons, when the vapor pressure deficit and the evaporative demand are higher [171]. This was made by leaning grapevine canopy $30^{\circ}$ to the West, which resulted in increases of $13 \%$ in leaf area, $12 \%$ in yield, and $11 \%$ in water-use efficiency when compared to the typical vertical shoot positioning system [171]. This pioneering study proved that leaning canopies to the west could be a useful tool for modulating vineyard water management under Mediterranean semi-arid conditions.

When water is a limiting factor, close row spacing increases water use because sunlight interception is providing the driving energy for transpiration. Therefore, an alternative to improve vineyard resistance to drought is to increase row spacing, consequently reducing vine density. A recent study simulated the effect of three row spacings on vineyard water balance under three different conditions of soil water availability [172]. This approach demonstrated that vine spacing had a relevant effect on water balance and water availability during grape ripening. However, increased vine spacing reduces both yield and production costs, so the profitability of the vineyard depends on the trade-off between these two effects [172].

These studies highlight the fact that the planning of the vineyard prior to its plantation should consider these issues for solving problems related to water availability that could appear in the future. However, other canopy management techniques can be used to modify water management when the vineyard is already established, such as green pruning [173]. The goal of green pruning is to remove excess shoots to balance the vegetative growth and the yield in the grapevine. This helps managing the water use of the grapevine. The timing of green pruning can be used in combination with cover crop management to modulate water dynamics in an intermediate scale between plot planning and irrigation scheduling. However, this practice is costly because it must be carried out by skilled personnel.

\section{Irrigation in Vineyards: Strategies and Advantages}

The irrigation of grapevines has become an important management practice to guarantee yield stability, wine quality, and even plant survival in regions affected by seasonal drought [144]. However, irrigating vineyards is not always possible because of several reasons, including the restrictions imposed by the geographical indications ("Denominación de Origen", "Appelation d'Origine", or "Herkunftsbezeichning") as well as other norms that may forbid it, the lack of concessions of water for irrigation, and because, in the context of climate change, there may be not enough water for irrigation. In addition, supplying irrigation to ensure the full vine evapotranspiration may maximize vineyard productivity, but it reduces berry and wine quality. Therefore, irrigation must be controlled to optimize the balance between vegetative growth and yield, avoiding an excessive vigor [2] Moreover, despite the fact that irrigation is common in the viticulture of the New World countries, this practice was forbidden by law in some European countries until the late 1990s [27]. Consequently, an enormous research effort has been devoted to assess the effects that different irrigation protocols and systems may have on grapevine performance. In this context, a basic search in the Web of Science database performed on 11 September 2020 using "irrigation" and "vineyard" as search terms resulted in 1316 articles for the period from 1949 to 2020 . Figure 4 shows the number of resulting articles ordered by decade. An increasing interest in this subject can be observed from 2000 onwards (Figure 4). In the last five years (2016-2020), 443 articles dealing with vineyard irrigation have been published, 
mainly from countries facing water scarcity problems, including Spain, USA, Italy, China,

France, and Australia.

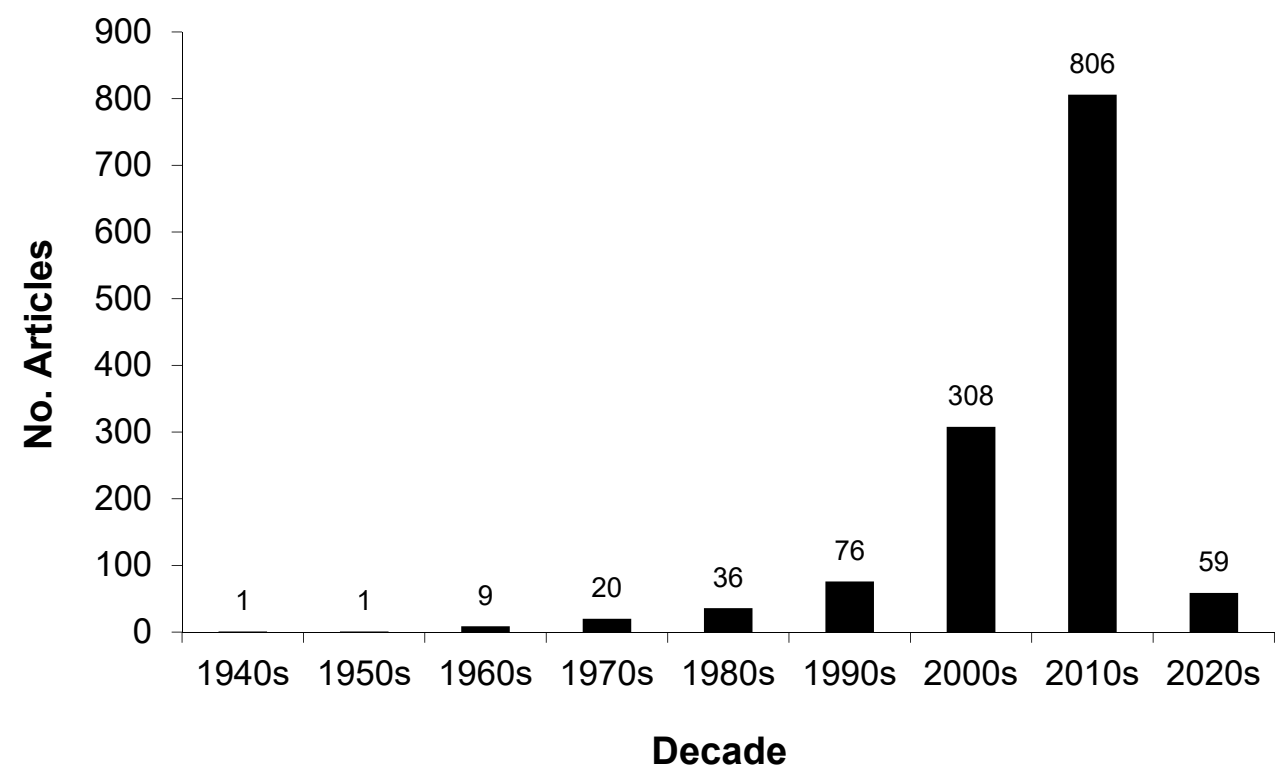

Figure 4. Number of articles dealing with irrigation and vineyard produced by a search in the Web of Science database performed on 11 September 2020.

The first studies on vineyard irrigation dealt with the application of a constant amount of water, less than the potential evapotranspiration, over the entire growing season $[174,175]$. These works showed a general increase in yield and, in some instances, also some beneficial effects on berry composition (such as higher acidity and increased berry sugar concentration). However, a decrease in anthocyanins concentration in berry skin was also observed [175].

The two irrigation techniques that have been more studied in vineyards are regulated deficit irrigation (RDI) and partial root-zone drying (PRD). In both cases, water applications replace only a percentage of the potential vine evapotranspiration, either over the entire season or only during some stages of the growing cycle, aiming to minimize yield reductions and improve grape composition [176,177].

The beneficial effects of RDI on grapevine can be summarized in (1) improvement of water-use efficiency; (2) reduction of heat stress; and/or (3) delay of grape ripening. Most of the research effort has been focused on red varieties, such as Cabernet Sauvignon, Syrah, Merlot, or Tempranillo [40,41,44,178]. These studies provided contrasting results depending on the grapevine variety considered and local conditions. However, when water resources are scarce, applying moderate water deficits before veraison and irrigation without considerable restrictions afterwards appeared as the most convenient strategy for improving berry composition while maintaining yield levels [27]. In contrast, studies on white varieties are less numerous. However, this trend has changed, and an increasing interest has been devoted to the assessment of the effects of RDI on renowned white varieties such as Sauvignon blanc [179,180], Chardonnay [46,181,182], Airén [183], Muscat of Alexandria [184], or Albariño [48]. These studies proved that RDI improved vine water status, increased yield, and affected positively the wine sensory profiles [46]. This continuous research has provided some certainties, including the fact that irrigation restriction before veraison is an effective way to control berry size, while water restriction after veraison affects grape composition [27]. However, some inconsistencies exist among studies due to differences in soil, grapevine cultivar, and environmental conditions. Interestingly, current research focused on lesser-known grapevine varieties such as Arvine [185], Carménère [186], Godello and Treixadura [187], Sangiovese [188], and Verdejo [189]. These studies broadened the spectrum of available information and provided interesting findings 
on the performance of these cultivars under different irrigation regimes, concluding that high water availability increased yield while must and wine composition were affected negatively on some years. However, consistent results were not observed among studies, suggesting that more research efforts are needed to fully elucidate the responses of particular combinations of rootstocks and scions under a wide range of climate and soil conditions.

In the case of PRD, the irrigation zones are alternated, generally every 15 or 20 days, with half of the root system kept dry while the other half receives irrigation. The major effect of PRD on grapevines is the production of chemical signals in drying roots, which are transported to the leaves where they trigger a reduction in stomatal conductance [190]. This reduces transpiration without any major effect on plant growth or productivity. In the field, PRD has produced positive results in terms of controlling excessive vegetative growth and improving grape quality while contributing to water savings of close to $50 \%$ without impairing fruit production [191-194]. Nevertheless, other studies reported that PRD did not have any considerable effect on grapevine performance when it was compared with the same amount of water applied through conventional drip irrigation [195,196]. Furthermore, results from a study in a Tempranillo vineyard suggested that the irrigation amount rather than the system of application was the main factor influencing vine performance [197]. These contrasting results pointed out the difficulties of implementing PRD strategies in vineyards. It seems that PRD provided best results in sandy soils [192] than in heavy and deep soils [196,197]. Nonetheless, recent studies about PRD confirmed, under two soil types, the usefulness of this irrigation strategy for saving water while maintaining fruit yield and improving wine quality through increases in polyphenol contents [194].

More recent research efforts are focused on addressing unresolved questions such as the effects of post-harvest RDI [182], the use of direct root-zone irrigation [198], or the combination of RDI and other practices such as variable crop load [199] and under-trellis cover crops [164]. Moreover, the effects of irrigation on vineyards located on reclaimed land have been the focus of a recent study [200]. However, researchers are still interested in understanding the behavior of well-known grapevine varieties, such as Cabernet Sauvignon, in different regions such as Spain [201], Israel [202], or China [203]. In this sense, multi-scale and multi-lever approaches to quantify the feasibility and effectiveness of the irrigation practices are required [204].

The accumulation of carbohydrates occurs during post-harvest, and it affects vegetative growth and yield in the following season, so adopting RDI during this period can be problematic [182]. When comparing three levels of RDI with a fully irrigated control in Chardonnay, yield components did not differ among treatments, but differences in berry composition were detected [182]. Even though this study indicated that adopting a RDI strategy during post-harvest could be inappropriate, it may be considered in a scenario of water restriction because there was less impact on yield and berry composition than if RDI had been adopted during pre-harvest [182]. Another study on this issue reported that water restriction during post-harvest affected the formation of new roots but not starch concentration in perennial organs of Chardonnay grapevines [205].

In a Cabernet Sauvignon vineyard located in a semi-arid region of south-central Washington State (USA), a comparison of a novel subsurface drip irrigation strategy against traditional irrigation methods was performed [198]. This comparison involved plant water status, root traits, yield, berry composition, and crop water-use efficiency. The authors observed that compared to surface drip irrigation, direct root-zone irrigation improved grape yield by $9-12 \%$ and crop water-use efficiency by $9-11 \%$, with minor effects on berry composition [198]. In addition, deep rooting seemed to be favored by this novel irrigation strategy. This technique is an extension of subsurface drip irrigation (SDI) systems that use buried drip lines, which are difficult to monitor, repair, and adjust to meet needs based on the type and age of perennial crops [206]. Moreover, these systems tend to concentrate the wetting zone, possibly restricting root distribution [207]. However, SDI systems have shown promise for improving grape yield and water-use efficiency $[207,208]$. 
Analytical techniques [209] allowed for determining secondary metabolites in the berries and volatile compounds in the wines in an accurate and cost-effective manner, so current research on the deficit irrigation of vineyards is increasingly addressing these aspects. Among these compounds, research efforts focused on amino acids, anthocyanins, polyphenols, and aromatic volatiles.

Amino acids are secondary metabolites that have an impact on wine aroma, since some of them are precursors of volatile compounds. Consequently, researchers focused on the effects of water deficit on their metabolism in the grapes [210], concluding that proline concentrations increase with water deficit in red cultivars, but no clear patterns were observed in white cultivars. In the field, current research proved that irrigation decreased the concentrations of some amino acids such as cysteine, tryptophan, and phenylalanine in the musts from the Treixadura cultivar [47], but it did not affect the concentrations of amino acids in musts from Albariño [211], Godello [212], and Chardonnay [213] cultivars. Therefore, cultivar and environmental conditions are key factors in the response of grape amino acids to irrigation, ensuring further research on these aspects.

Regarding berry and wine volatile composition, irrigation effects strongly depend on the grapevine cultivar and the environmental conditions [48]. A comprehensive study on the Viognier cultivar reported that pre-veraison water deficit tended to increase the concentrations of volatile compounds in the berries, while a post-veraison water restriction tended to reduce the contents of these compounds [214]. More specifically, irrigation tended to reduce the concentrations of isoamyl acetate, 2-phenylethyl acetate, and ethyl hexanoate in Albariño wines [215], while no clear effects were observed in Godello wines [212], and Treixadura wines [47]. In Verdejo wines, irrigation tended to reduce the concentrations of volatile phenols and C6 compounds [189]. A recent study on the Gewürztraminer cultivar reported that late deficit irrigation increased the concentrations of geraniol and citronellol in the berries but did not affect total free and bound terpenes [216]. These findings suggest the need for further research about the RDI effects on the biochemical pathways of secondary metabolites in grapes from different varieties and grown under different environments. Moreover, the effects of RDI on wine volatile composition and sensory profiles deserve further investigation.

In view of the results from these studies, optimal irrigation strategies are difficult to generalize due to the complexity and heterogeneity of vineyards, so suitable physiological indices and thresholds to manage RDI have been proposed to achieve high-quality grapes under different environmental conditions [125,217]. In this context, recent investigations proved the potential of variable-rate irrigation to manage the spatial heterogeneity within the vineyard, showing reductions of $18 \%$ in water use without losses in yield and grape composition while achieving a more homogeneous grape maturation [218]. In addition, the long-term effects of deficit irrigation strategies should be considered, due to the risk of a gradual reduction in yield and vegetative growth $[219,220]$. Furthermore, despite the great research effort regarding irrigation management in vineyards, little is known about the effects of fertigation on grapevine performance due to a lack of studies [221,222], and further research is needed. Another aspect to consider is the use of reclaimed wastewater or other water resources of variable quality for irrigation purposes, whose usage is increasing within the horticultural sector, including winegrape production [223], in order to conserve water of better quality and divert it to other users. Therefore, it is imperative to understand the short- and long-term implications of the use of these water resources in order to optimize water conservation without compromising soil and plant health [22,223].

\section{New Technologies to Improve Vineyard Water Management: Models, Proximal and Remote Sensing}

As with many other fields in research, new technologies are increasingly being used. In the case of vineyard management, models, proximal and remote sensing are the most commonly used technologies. In this section, they will be briefly described. 


\subsection{Models}

To cope with the inherent complexity of grapevine performance and the interrelated factors that exert an influence on it, as well as on berry composition, process-based models show a promising ability to integrate physiological data, generate novel hypothesis, and provide a wider picture of berry growth, yield, and quality development [224]. In the case of grapevines, modeling efforts have focused on explaining shoot growth, dry mass accumulation, and canopy structure $[225,226]$. Concerning water use by grapevines, research focused on the simulation of the evolution of berry fresh and dry mass and sugar accumulation after veraison, accounting for the effects of leaf-to-fruit-ratio and water stress on these traits [227].

Recent research on the physiology of grapevine under water stress conditions identified the role of rootstock in grapevine water relations [228]. These authors concluded that differences in root architecture explained the higher transpiration rates in Cabernet Sauvignon under low to moderate water deficit when grafted onto a drought-tolerant rootstock [228]. They also pointed out the relevance of chemical signals, such as the abscisic acid, in the role that rootstocks play in grapevine physiology [228]. In this line of work focused on grapevine physiology, a recent article described the development of a comprehensive functional-structural model that coupled the dynamics of water transport within the grapevine with leaf gas exchange [229]. The model was able to predict photosynthesis, transpiration, stomatal conductance, and leaf water potential as a function of the patterns of soil drying. These promising results allowed for illustrating that grapevines strive to maintain proper berry ripening by partially compensating for a reduced source-sink ratio, and that under drought, an enhanced berry sucrose uptake capacity can reverse berry shrinkage [230]. These studies demonstrated the usefulness of the model presented for understanding the physiology and growth of individual plant organs, as well as berry fruit growth, in relation to plant water status $[229,230]$. Unfortunately, despite their undoubtable relevance and usefulness, these models are complex and difficult to apply for managing water in vineyards.

Consequently, the research effort on optimizing water use in vineyards was directed toward the development of soil water balance models adapted to this crop [231]. This allowed obtaining fair estimates of seasonal water balance dynamics in two different vineyards and a relation of this balance with pre-dawn water potential that could be used for scheduling irrigation [231]. In the context of modeling soil water balance, accurate estimates of reference evapotranspiration are required [232,233], which can be obtained using satellite-sensed solar radiation in areas where air temperature is the sole local weather variable available [234]. Moreover, crop coefficients for grapevine can be estimated accurately by using plant height and the fraction of ground cover [235], improving the estimations of vineyard water needs, as made in other woody crops such as orange trees [236]. Another approach is the adaptation of existing models to grapevine, which has given promising results [237].

However, soil contribution to grapevine water status varies in space and time at a fine scale $[12,238]$. Moreover, this is affected by the inherent spatial variability of rainfall [239]. Therefore, it is necessary to extrapolate the estimations or measurements of grapevine water status from a reference site to the whole vineyard [240]. This can be achieved by separating the effects of soil water availability and those of climatic conditions on grapevine water status [241]. Another approach that is being explored currently is the modification of the surface energy balance for taking into account partial wetting in irrigated vineyards [242]. This modeling approach can be used to estimate the effect and significance of direct evaporation from wet and dry soil areas on the total evapotranspiration and to inform water balance studies for optimizing irrigation management [242]. Finally, the most recent approaches employ artificial intelligence for estimating how weather and vineyard water management affect wine aroma, which could help adjust some practices to maintain or enhance the quality of wines, or maintain the wine style associated to a specific region [243]. 


\subsection{Proximal Sensing}

It is widely recognized that electromagnetic induction sensors (Figure 5) can provide useful information on the spatial variability of certain soil properties within a given field [244]. These sensors provide a measure of the soil apparent electrical conductivity that is an indirect indicator of relevant soil properties such as salinity, clay, and soil water content, among others [244]. In vineyards, these measurements have been correlated with vine stem water potential and berry composition [245]. This limitation comes from the fact that these measurements are usually related to soil properties through purely empirical correlations, which are site-specific and vary over time [244,246]. In a recent study, a semiempirical model represented the underlying physical process that affects electromagnetic induction signals and provided the basis for planning and comparing these measurements among different areas [246]. However, the use of these sensors in vineyard management is nowadays limited to the delineation of site-specific management zones $[10,247,248]$, which can be useful for precise and optimal irrigation scheduling.

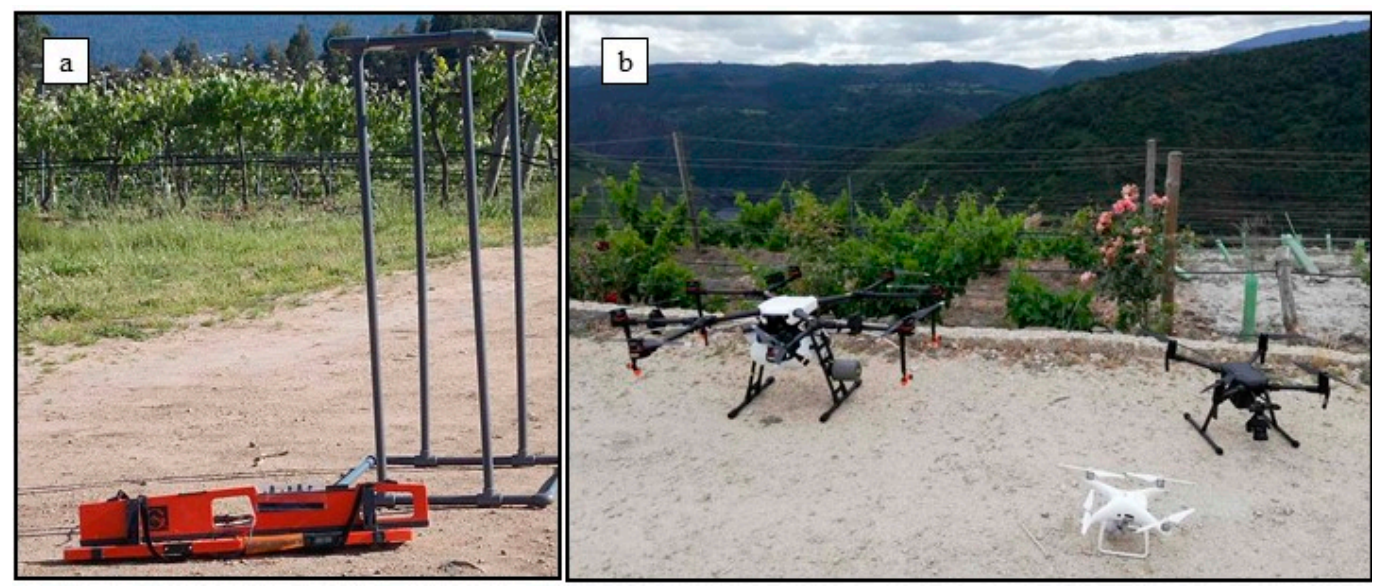

Figure 5. Examples of equipment for proximal and remote sensing employed in vineyards: (a) Electromagnetic induction sensor with plastic structure for its calibration; (b) Three different models of unmanned aerial vehicles. Photos were taken by J.M. Mirás-Avalos.

\subsection{Remote Sensing}

The increased computing power, the rise of remotely piloted aircraft systems (Figure 5), and the advances in image processing increase the opportunities for vineyard observations through remote sensing [249]. The link between wine attributes and the environment is a crucial step for identifying the factors that influence terroir [250]. Therefore, highquality contiguous spatial data of the physical parameters (including soil water content) are required. Remote sensing is the primary tool for acquiring such data [249].

Nowadays, viticulturists have many options for the acquisition of remotely sensed image data that could provide useful information: optical, thermal, light distancing and ranging (LiDAR), microwave, and fluorescence remote sensing [251]. Thermal remote sensing is particularly useful for measuring spatial variability in vine transpiration [252], and, by inference, water stress. Moreover, vegetation indices that combine spectral bands sensitive to vegetation density are generally derived from multi-spectral imagery to enable the analysis of vineyard canopy [249]. With the increasing accessibility of remotely piloted aircraft systems as platforms for remote sensing devices, and the availability of satellite images, remote-sensing image data of vineyards are becoming more accessible and significantly lower in cost [249].

The current article does not try to summarize all the advantages and capabilities of remote sensing techniques for their application in vineyards, but it will focus on the most recent findings regarding vineyard water management through these tools. In this sense, strong correlations between soil characteristics (such as plant-available water-holding 
capacity), vine nutrition, and the sensory properties of finished wines have been demonstrated within different zones identified from a combination of spatial data describing environmental conditions [253].

Complicated models for extrapolating water status measurements from grapevines located on a single reference site to the entire vineyard have been proposed [254]. However, remote sensing technologies can facilitate this task and provide reliable estimates of the spatial distribution of vine water status within a vineyard. In this sense, a combination of remote and proximal sensing technologies, along with statistical methods, allowed discriminating irrigation water management effects in vineyards trained to a pergola system under humid climate conditions [245]. Recently, some authors coupled multi-spectral imagery with machine learning algorithms in order to schedule irrigation [255]. These authors developed several models based on artificial neural networks and obtained promising results for irrigation scheduling purposes using thresholds of stem water potential as outputs. They concluded that their model could be applied to analyze on a plant-by-plant basis, to identify sectors of stress within the vineyard for optimal water management, and to identify spatial variability within vineyards [255].

Indeed, precision water management in vineyards may benefit from the quantification of within-field spatial variability and temporal patterns of grapevine transpiration [256]. In this sense, a combination of time-series decomposition of evapotranspiration retrievals from multiple satellite platforms and a random forest classification algorithm has been tested in a Pinot noir vineyard in California [256]. This approach showed high prediction accuracy and revealed that the area of the vineyard planted on top of a silt loam soil had better conditions to consume more water. These findings allowed the spatial quantification of evapotranspiration time series at different temporal scales and may benefit within-season decision-making regarding the amounts, timing, and location of irrigation [256].

Another study evaluated the extent to which high-resolution thermal imaging allows the assessment of instantaneous and seasonal variability of vineyard water status [257]. The authors designed and built an unmanned aerial vehicle for providing very high-resolution imaging (pixel $<9 \mathrm{~cm}$ ) and applied it at a relevant scale $(7.5 \mathrm{ha})$ for obtaining crop water stress index estimates from thermal images in a clear-sky day. Then, they compared the values of this index to stem water potential and stomatal conductance measured at 14 sampling sites within the vineyard. Strong correlations were obtained between remotesensing data and ground measurements, allowing for producing spatial estimations of grapevine water status across the vineyard. Therefore, the information provided by thermal images proved to be relevant at a seasonal scale, as well as to map instantaneous variations in water status within a vineyard. However, the acquisition of thermal images at several dates along the summer was recommended for ensuring an accurate estimation of water status variations [257].

Other studies focused on the use of estimations of thermal balance through satellite images to estimate evapotranspiration over vineyards at different scales [258-260]. In this line of work, the feasibility of using Sentinel-2 and Sentinel-3 images for increasing the temporal resolution of vineyard water status estimates has been recently assessed [258]. This report compared several methodologies and concluded that the use of the two-source energy balance model with land surface temperature images retrieved from Sentinel-2 and Sentinel-3 satellites and the Shuttleworth-Wallace model was adequate for assessing the actual evapotranspiration from grapevines across the growing season [258].

Other works described relatively simple methods for irrigation water accounting at the plot and water user association scales [259]. The combined use of the dual crop coefficient FAO56 methodology and a soil water balance based on remote sensing images offered reproducible and reliable maps of vineyard water requirements that can be useful for water managers to make informed decisions [259]. The use of other remote sensing products, such as land surface temperature and vegetation indices, combined with large aperture scintillometer measurements can provide accurate estimates of vineyard water requirements $[15,260]$. 
As it can be gathered from the mentioned examples, this field of research is extremely dynamic, and new technologies and algorithms emerge almost on a weekly basis. However, the main challenge of remote sensing for optimizing water management in vineyards is the development of an accurate, reliable, easy-to-use, and cost-effective tool that can be employed by a great number of viticulturists and wineries.

\section{Conclusions and Perspectives}

The comprehensive review undertaken in this study highlighted the tremendous effort made by the scientific community to solve one of the main challenges that viticulture is facing nowadays: water scarcity. Researchers have made great and relevant advancements on the optimization of irrigation management, especially on red and well-known cultivars (Cabernet Sauvignon, Merlot, Syrah, Tempranillo), on remote sensing tools for estimating vineyard water requirements and on the effects of water stress on the physiological and metabolic pathways, leading to the formation of secondary metabolites in the berries. However, there are still many questions to address in the future in order to get relevant information for achieving vineyard sustainability under the conditions imposed by climate change (reduced water availability, increasing temperatures, and increment in the incidence and intensity of extreme weather events).

From the information presented in this review, the main aspects that researchers should address during the next years should be the following:

- Multifactorial studies: Usually, the research that has been performed until the present was focused on the evaluation of the effects of a single stressor on grapevine response. However, several studies pointed out the great number of interrelations and the complexity of the links among several stressors (drought, soil salinity, disease pressure, plant-insect interactions, heat waves, etc.) on the final response of the vines. Therefore, broadening the scope of the studies to account for several stressors and evaluating their joint effects on grapevines should be a priority.

- The development of a non-destructive, cost-effective, and easy-to-use method for monitoring continuously grapevine water status is a challenge to address in the future. In this context, remote sensing and machine learning techniques can provide helpful information to develop models for upscaling the measurements obtained.

- Future studies should focus on less-known varieties because research has proven that grapevine response to water restrictions is genotype-dependent. In this context, several rootstock-scion combinations need to be tested. Moreover, management practices alone or in combination with irrigation, either on well-known or less-known grapevine varieties, will be an asset that future research needs to address.

- The effects of water stress on secondary metabolites and on wine volatile composition need to be clearly elucidated.

Addressing these aspects is a great challenge, but the foundations have already been set, and one can be confident that in the next few years, the scientific community will obtain sound conclusions about some of the topics and questions raised in this review.

Author Contributions: Conceptualization, J.M.M.-A.; methodology and literature search, J.M.M.-A. and E.S.A.; validation, J.M.M.-A. and E.S.A.; investigation, J.M.M.-A. and E.S.A.; writing-original draft preparation, J.M.M.-A. and E.S.A.; writing—review and editing, J.M.M.-A. and E.S.A.; supervision, J.M.M.-A. All authors have read and agreed to the published version of the manuscript.

Funding: This research received no external funding.

Institutional Review Board Statement: Not applicable.

Informed Consent Statement: Not applicable.

Data Availability Statement: Data sharing not applicable.

Conflicts of Interest: The authors declare no conflict of interest. 


\section{References}

1. Organisation International de la Vigne et du Vin (OIV). 2019 Statistical Report on World Viticulture. Available online: http: // oiv.int/public/medias/6782/oiv-2019-statistical-report-on-world-vitiviniculture.pdf (accessed on 21 October 2020).

2. Jackson, D.I.; Lombard, P.B. Environmental and management practices affecting grape composition and wine quality-A review. Am. J. Enol. Vitic. 1993, 44, 409-430.

3. Deloire, A.; Carbonneau, A.; Wang, Z.; Ojeda, H. Vine and water: A short review. J. Int. Sci. Vigne Vin 2004, 38, 1-13. [CrossRef]

4. Jones, G.V. The climate component of Terroir. Elements 2018, 14, 167-172. [CrossRef]

5. Fayolle, E.; Follain, S.; Marchal, P.; Chéry, P.; Colin, F. Identification of environmental factors controlling wine quality: A case study in Saint-Emilion Grand Cru appellation, France. Sci. Total Environ. 2019, 694, 133718. [CrossRef]

6. Fraga, H.; Malheiro, A.C.; Moutinho-Pereira, J.; Cardoso, R.M.; Soares, P.M.M.; Cancela, J.J.; Pinto, J.G.; Santos, J.A. Integrated analysis of climate, soil, topography and vegetative growth in Iberian viticultural regions. PLoS ONE 2014, 9, e108078. [CrossRef] [PubMed]

7. Constantini, E.A.C.; Castaldini, M.; Diago, M.P.; Giffard, B.; Lagomarsino, A.; Schroers, H.J.; Priori, S.; Valboa, G.; Agnelli, A.E.; Akça, E.; et al. Effects of soil erosion on agro-ecosystem services and soil functions: A multidisciplinary study in nineteen organically farmed European and Turkish vineyards. J. Environ. Manag. 2018, 223, 614-624. [CrossRef] [PubMed]

8. Priori, S.; Pellegrini, S.; Perria, R.; Puccioni, S.; Storchi, P.; Valboa, G.; Constantini, E.A.C. Scale effect of terroir under three contrasting vintages in the Chianti Classico area (Tuscany, Italy). Geoderma 2019, 334, 99-112. [CrossRef]

9. Garcia, L.; Celette, F.; Gary, C.; Ripoche, A.; Valdés-Gómez, H.; Metay, A. Management of service crops for the provision of ecosystem services in vineyards: A review. Agric. Ecosys. Environ. 2018, 251, 158-170. [CrossRef]

10. Mirás-Avalos, J.M.; Fandiño, M.; Rey, B.J.; Dafonte, J.; Cancela, J.J. Zoning of a newly-planted vineyard: Spatial variability of physico-chemcial soil properties. Soil Syst. 2020, 4, 62. [CrossRef]

11. Srivastava, A.; Saco, P.M.; Rodriguez, J.F.; Kumari, N.; Chun, K.P.; Yetemen, O. The role of landscape morphology on soil moisture variability in semi-arid ecosystems. Hydrol. Proces. 2021, 35, e13990. [CrossRef]

12. Jasse, A.; Berry, A.; Aleixandre-Tudo, J.L.; Poblete-Echeverría, C. Intra-block spatial and temporal variability of plant water status and its effect on grape and wine parameters. Agric. Water Manag. 2021, 246, 106696. [CrossRef]

13. Schultz, H.R.; Jones, G.V. Climate induced historic and future changes in viticulture. J. Wine Res. 2010, 21, 137-145. [CrossRef]

14. Neethling, E.; Barbeau, G.; Coulon-Leroy, C.; Quénol, H. Spatial complexity and temporal dynamics in viticulture: A review of climate-driven scales. Agric. Forest Meteorol. 2019, 276-277, 107618. [CrossRef]

15. Kumari, N.; Saco, P.M.; Rodriguez, J.F.; Johnstone, S.A.; Srivastava, A.; Chun, K.P.; Yetemen, O. The grass is not always greener on the other side: Seasonal reversal of vegetation greenness in aspect-driven semiarid ecosystems. Geophys. Let. 2020, 47, e2020GL088918. [CrossRef]

16. Santos, J.A.; Fraga, H.; Malheiro, A.C.; Moutinho-Pereira, J.; Dinis, L.T.; Correia, C.; Moriondo, M.; Leolini, L.; Dibari, C.; Costafreda-Aumedes, S.; et al. A review of the potential climate change impacts and adaptation options for European viticulture. Appl. Sci. 2020, 10, 3092. [CrossRef]

17. Medrano, H.; Tomás, M.; Martorell, S.; Escalona, J.M.; Pou, A.; Fuentes, S.; Flexas, J.; Bota, J. Improving water use efficiency of vineyards in semi-arid regions. A review. Agron. Sust. Develop. 2015, 35, 499-517. [CrossRef]

18. Fraga, H.; García de Cortázar Atauri, I.; Santos, J.A. Viticultural irrigation demands under climate change scenarios in Portugal. Agric. Water Manag. 2018, 196, 66-74. [CrossRef]

19. van Leeuwen, C.; Destrac-Irvine, A.; Dubernet, M.; Duchêne, E.; Gowdy, M.; Marguerit, E.; Pieri, P.; Parker, A.; de Rességuier, L.; Ollat, N. An update on the impact of climate change in viticulture and potential adaptations. Agronomy 2019, 9, 514. [CrossRef]

20. Intergovernmental Panel on Climate Change (IPCC). Climate Change 2014: Synthesis Report. Contribution of Working Groups I, II and III to the Fifth Assessment Report of the Intergovernmental Panel on Climate Change; Pachauri, R.K., Meyer, L.A., Eds.; IPCC: Geneva, Switzerland, 2014; p. 151.

21. Williams, L.E.; Ayars, J.E. Grapevine water use and the crop coefficient are linear functions of the shaded area measured beneath the canopy. Agric. Forest Meteorol. 2005, 132, 201-211. [CrossRef]

22. Costa, M.; Vaz, M.; Escalona, J.; Egipto, R.; Lopes, C.; Medrano, H.; Chaves, M. Modern viticulture in southern Europe: Vulnerabilities and strategies for adaptation to water scarcity. Agric. Water Manag. 2016, 164, 5-18. [CrossRef]

23. Ungureanu, N.; Vlădut, V.; Voicu, G. Water scarcity and wastewater reuse in crop irrigation. Sustainability 2020, $12,9055$. [CrossRef]

24. Neupane, J.; Guo, W. Agronomic basis and strategies for precision water management: A review. Agronomy 2019, 9, 87. [CrossRef]

25. Marín, D.; Armengol, J.; Carbonell-Bejerano, P.; Escalona, J.M.; Gramaje, D.; Hernández-Montes, E.; Intrigliolo, D.S.; MartínezZapater, J.M.; Medrano, H.; Mirás-Avalos, J.M.; et al. Challenges of viticulture adaptation to global change: Tackling the issue from the roots. Aus. J. Grape Wine Res. 2021, 27, 8-25. [CrossRef]

26. Santillán, D.; Iglesias, A.; La Jeunesse, I.; Garrote, L.; Sotes, V. Vineyards in transition: A global assessment of the adaptation needs of grape producing regions under climate change. Sci. Total Environ. 2019, 657, 839-852. [CrossRef]

27. Ruiz-Sánchez, M.C.; Domingo, R.; Castel, J.R. Review. Deficit irrigation in fruit trees and vines in Spain. Span. J. Agric. Res. 2010, 8, S5-S20. [CrossRef]

28. Phogat, V.; Cox, J.W.; Mallants, D.; Petrie, P.R.; Oliver, D.P.; Pitt, T.R. Historical and future trends in evapotranspiration components and irrigation requirement of winegrapes. Aus. J. Grape Wine Res. 2020, 26, 312-324. [CrossRef] 
29. Scholasch, T.; Rienth, M. Review of water deficit mediated changes in vine and berry physiology; consequences for the optimization of irrigation strategies. OENO One 2019, 53, 423-444. [CrossRef]

30. Gambetta, G.A.; Herrera, J.C.; Dayer, S.; Feng, Q.; Hochberg, U.; Castellarin, S.D. The physiology of drought stress in grapevine: Towards an integrated definition of drought tolerance. J. Exp. Bot. 2020, 71, 4658-4676. [CrossRef] [PubMed]

31. Keller, M. Managing grapevines to optimise fruit development in a challenging environment: A climate change primer for viticulturists. Aus. J. Grape Wine Res. 2010, 16, 56-69. [CrossRef]

32. Guilpart, N.; Metay, A.; Gary, C. Grapevine bud fertility and number of berries per bunch are determined by water and nitrogen stress around flowering in the previous year. Eur. J. Agron. 2014, 54, 9-20. [CrossRef]

33. Hardie, W.J.; Considine, J.A. Response of grapes to water-deficit stress in particular stages of development. Am. J. Enol. Vitic. 1976, 27, 55-61.

34. Molitor, D.; Bans, O.; Hoffmann, L.; Beyer, M. Meteorological conditions determine the thermal-temporal position of the annual Botrytis bunch rot epidemic on Vitis vinifera L. cv. Riesling grapes. OENO One 2016, 50, 231-244. [CrossRef]

35. Jones, G.V.; Davis, R.E. Using a synoptic climatological approach to understand climate-viticulture relationships. Int. J. Clim. 2000, 20, 813-817. [CrossRef]

36. Ramos, M.C.; Jones, G.V.; Martínez-Casasnovas, J.A. Structure and trends in climate parameters affecting winegrape production in northeast Spain. Clim. Res. 2008, 38, 1-15. [CrossRef]

37. Reynolds, A.G.; Naylor, A.P. Pinot-Noir and Riesling grapevines respond to water-stress duration and soil water-holding capacity. HortScience 1994, 29, 1505-1510. [CrossRef]

38. Bonada, M.; Edwards, E.J.; McCarthy, M.G.; Sepúlveda, G.C.; Petrie, P.R. Impact of low rainfall during dormancy on vine productivity and development. Aus. J. Grape Wine Res. 2020, 26, 325-342. [CrossRef]

39. Ojeda, H.; Andary, C.; Kraeva, E.; Carbonneau, A.; Deloire, A. Influence of pre- and postveraison water deficit on synthesis and concentration of skin phenolic compounds during Berry growth of Vitis vinifera cv. Shiraz. Am. J. Enol. Vitic. 2002, 53, $261-267$.

40. Chapman, D.W.; Roby, G.; Ebeler, S.E.; Guinard, J.X.; Matthews, M.A. Sensory attributes of Cabernet Sauvignon wines made from vines with different water status. Aus. J. Grape Wine Res. 2005, 11, 339-347. [CrossRef]

41. Bindon, K.; Myburgh, P.; Oberholster, A.; Roux, K.; Du Toit, C. Response of grape and wine phenolic composition in Vitis vinifera L. cv. Merlot to variation in grapevine water status. S. Afr. J. Enol. Vitic. 2011, 32, 71-88. [CrossRef]

42. Ollé, D.; Guiraud, J.L.; Souquet, J.M.; Terrier, N.; Ageorges, A.; Cheynier, V.; Verries, C. Effect of pre- and post-veraison water deficit on proanthocyanidin and anthocyanin accumulation during Shiraz berry development. Aus. J. Grape Wine Res. 2011, 17, 90-100. [CrossRef]

43. Santesteban, L.G.; Miranda, C.; Royo, J.B. Regulated deficit irrigation effects on growth, yield, grape quality and individual anthocyanin composition in Vitis vinifera L. cv. 'Tempranillo'. Agric. Water Manag. 2011, 98, 1171-1179. [CrossRef]

44. Intrigliolo, D.S.; Pérez, D.; Risco, D.; Yeves, A.; Castel, J.R. Yield components and grape composition responses to seasonal water deficits in Tempranillo grapevines. Irrig. Sci. 2012, 30, 339-349. [CrossRef]

45. Cook, M.G.; Zhang, Y.; Nelson, C.J.; Gambetta, G.; Kennedy, J.A.; Kurtural, S.K. Anthocyanin composition of Merlot is ameliorated by light microclimate and irrigation in Central California. Am. J. Enol. Vitic. 2015, 66, 266-278. [CrossRef]

46. Balint, G.; Reynolds, A.G. Irrigation level and time of imposition impact vine physiology, yield components, fruit composition and wine quality of Ontario Chardonnay. Sci. Hortic. 2017, 214, 252-272. [CrossRef]

47. Bouzas-Cid, Y.; Falqué, E.; Orriols, I.; Mirás-Avalos, J.M. Effects of irrigation over three years on the amino acid composition of Treixadura (Vitis vinifera L.) musts and wines, and on the aromatic composition and sensory profiles of its wines. Food Chem. 2018, 240, 707-716. [CrossRef]

48. Vilanova, M.; Fandiño, M.; Frutos-Puerto, S.; Cancela, J.J. Assessment fertigation effects on chemical composition of Vitis vinifera L. cv. Albariño. Food Chem. 2019, 278, 636-643. [CrossRef]

49. Roby, G.; Habbertson, J.F.; Adams, D.A.; Matthews, M.A. Berry size and vine water deficits as factors in winegrape composition: Anthocyanins and tannins. Aus. J. Grape Wine Res. 2004, 10, 100-107. [CrossRef]

50. Mirás-Avalos, J.M.; Buesa, I.; Yeves, A.; Pérez, D.; Risco, D.; Castel, J.R.; Intrigliolo, D.S. Unravelling the effects of berry size on 'Tempranillo' grapes under different field practices. Ciência Téc. Vitiv. 2019, 34, 1-14. [CrossRef]

51. Mirás-Avalos, J.M.; Intrigliolo, D.S. Grape composition under abiotic constrains: Water stress and salinity. Front. Plant. Sci. 2017, 8, 851. [CrossRef] [PubMed]

52. Savoi, S.; Herrera, J.C.; Carlin, S.; Lotti, C.; Bucchetti, B.; Peterlunger, E.; Castellarin, S.D.; Mattivi, F. From grape berries to wines: Drounght impacts on key secondary metabolites. OENO One 2020, 54, 569-582. [CrossRef]

53. Chaves, M.M.; Pereira, J.S.; Maroco, J.; Rodrigues, M.L.; Ricardo, C.P.P.; Osório, M.L.; Carvalho, I.; Faria, T.; Pinheiro, C. How plants cope with water stress in the field. Photosynthesis and growth. Ann. Bot. 2002, 89, 907-916. [CrossRef] [PubMed]

54. Lavoie-Lamoureux, A.; Sacco, D.; Rissé, P.A.; Lovisolo, C. Factors influencing stomatal conductance in response to water availability in grapevine: A meta-analysis. Physiol. Plant. 2017, 159, 468-482. [CrossRef]

55. Chaves, M.M.; Zarrouk, O.; Francisco, R.; Costa, J.M.; Santos, T.; Regalado, A.P.; Rodrigues, M.L.; Lopes, C.M. Grapevine under deficit irrigation: Hints from physiological and molecular data. Ann. Bot. 2010, 105, 661-676. [CrossRef]

56. Lovisolo, C.; Lavoie-Lamoureux, A.; Tramontini, S.; Ferrandino, A. Grapevine adaptations to water stress: New perspectives about soil/plant interactions. Theor. Exp. Plant. Physiol. 2016, 28, 53-66. [CrossRef] 
57. Savoi, S.; Wong, D.C.; Arapitsas, P.; Miculan, M.; Bucchetti, B.; Peterlunger, E.; Fait, A.; Mattivi, F.; Castellarin, D. Transcriptome and metabolite profiling reveals that prolonged drought modulates the phenylpropanoid and terpenoid pathway in white grapes (Vitis vinifera L.). BMS Plant. Biol. 2016, 16, 67. [CrossRef]

58. Walker, R.R.; Blackmore, D.H.; Clingeleffer, P.R.; Emanuelli, D. Rootstock type determines tolerance of Chardonnay and Shiraz to long-term saline irrigation. Aus. J. Grape Wine Res. 2014, 20, 496-506. [CrossRef]

59. Songy, A.; Fernandez, O.; Clément, C.; Larignon, P.; Fontaine, F. Grapevine trunk diseases under thermal and water stresses. Planta 2019, 249, 1655-1679. [CrossRef] [PubMed]

60. Bruez, E.; Vallance, J.; Gerbore, J.; Lecomte, P.; Da Costa, J.P.; Guerin-Dubrana, L.; Rey, P. Analyses of the temporal dynamics of fungal communities colonizing the healthy wood tissues of esca leaf-symptomatic and asymptomatic vines. PLoS ONE 2014, 9, e95928. [CrossRef] [PubMed]

61. Úrbez-Torres, J.R. The status of Botryosphaeriaceae species infecting grapevines. Phytopathol. Mediterr. 2011, 50, 5-45. [CrossRef]

62. Herlemont, B.; Guérin-Dubrana, L.; Larignon, P. L'après arsénite, des alternatives à combiner: Vigne. Phytoma La Défense Des. Végétaux 2005, 587, 24-28.

63. Sosnowski, M.R.; Shtienberg, D.; Creaser, M.L.; Wicks, T.J.; Lardner, R.; Scott, E.S. The influence of climate on foliar symptoms of Eutypa dieback in grapevines. Phytopathology 2007, 97, 1284-1289. [CrossRef] [PubMed]

64. Veloso, J.; van Kan, J.A.L. Many shades of grey in Botrytis-host plant interactions. Trends Plant. Sci. 2018, 23, 613-622. [CrossRef] [PubMed]

65. Ferrer, M.; Echeverría, G.; Mirás-Avalos, J.M. Meteorological conditions: Influence on yield, sanitary status and grape composition. Int. J. Environ. Agric. Res. 2017, 3, 16-27. [CrossRef]

66. Coniberti, A.; Ferrari, V.; Disegna, E.; García Petillo, M.; Lakso, A.N. Complete vineyard floor cover crop to reduce grapevine susceptibility to bunch rot. Eur. J. Agron. 2018, 99, 167-176. [CrossRef]

67. Hatmi, S.; Trotel-Aziz, P.; Villaume, S.; Couderchet, M.; Clément, C.; Aziz, A. Osmotic stress-induced polyamine oxidation mediates defence responses and reduces stress-enhanced grapevine susceptibility to Botrytis cinerea. J. Exp. Bot. 2014, 65, 75-88. [CrossRef]

68. Guilpart, N.; Roux, S.; Gary, C.; Metay, A. The trade-off between grape yield and grapevine susceptibility to powdery mildew and grey mould depends on inter-annual variations in water stress. Agric. Forest Meteorol. 2017, 234, 203-211. [CrossRef]

69. Del Cid, C.; Krugner, R.; Zeilinger, A.R.; Daugherty, M.P.; Almeida, R.P.P. Plant water stress and vector feeding preference mediate transmission efficiency of a plant pathogen. Environ. Entomol. 2018, 47, 1471-1478. [CrossRef]

70. Almeida, R.P.P.; Nunney, L. How do plant diseases caused by Xylella fastidiosa emerge? Plant. Dis. 2015, 99, 1457-1467. [CrossRef]

71. Krugner, R.; Backus, E.A. Plant water stress effects on stylet probing behaviors of Homoladisca vitripennis (Hemiptera: Cicadellidae) associated with acquisition and inoculation of the bacterium Xylella fastidiosa. J. Econ. Entomol. 2014, 107, 66-74. [CrossRef]

72. Fernández, J.E. Plant-based methods for irrigation scheduling of woody crops. Horticulturae 2017, 3, 35. [CrossRef]

73. Rienth, M.; Scholasch, T. State-of-the-art of tools and methods to assess vine water status. OENO One 2019, 4, 619-637. [CrossRef]

74. de Pascale, S.; Rouphael, Y.; Gallardo, M.; Thompson, R.B. Water and fertilization management of vegetables: State of the art and future challenges. Eur. J. Hort. Sci. 2018, 83, 306-318. [CrossRef]

75. Ferrarezi, R.S.; Nogueira, T.A.R.; Zepeda, S.G.C. Performance of soil moisture sensors in Florida sandy soils. Water 2020, $12,358$. [CrossRef]

76. Zinkernagel, J.; Maestre-Valero, J.F.; Seresti, S.Y.; Intrigliolo, D.S. New technologies and practical approaches to improve irrigation management of open field vegetable crops. Agric. Water Manag. 2020, 242, 106404. [CrossRef]

77. Vanella, D.; Ramírez-Cuesta, J.M.; Sacco, A.; Longo-Minnolo, G.; Cirelli, G.L.; Consoli, S. Electrical resistivity imaging for monitoring soil water motion patterns under different drip irrigation scenarios. Irrig. Sci. 2020, 39, 145-157. [CrossRef]

78. Raffelli, G.; Previati, M.; Canone, D.; Gisolo, D.; Bevilacqua, I.; Capello, G.; Biddoccu, M.; Cavallo, E.; Deiano, R.; Cassiani, G.; et al. Local- and plot-scale measurements of soil moisture: Time and spatially resolved field techniques in plain, hill and mountain sites. Water 2017, 9, 706. [CrossRef]

79. Williams, L.E.; Trout, T.J. Relationships among vine and soil based measures of water status in a Thompson Seedless vineyard in response to high frequency drip irrigation. Am. J. Enol. Vitic. 2005, 56, 357-366.

80. Soulis, K.X.; Elmaloglou, S.; Dercas, N. Investigating the effects of soil moisture sensors positioning and accuracy on soil moisture based drip irrigation scheduling systems. Agric. Water Manag. 2015, 148, 258-268. [CrossRef]

81. Intrigliolo, D.S.; Castel, J.R. Vine and soil-based measures of water status in a Tempranillo vineyard. Vitis 2006, 45, 157-163. [CrossRef]

82. Martínez, E.M.; Rey, B.J.; Fandiño, M.; Cancela, J.J. Impact of water stress and nutrition on Vitis vinifera cv. 'Albariño': Soil-plant water relationships, cumulative effects and productivity. Span. J. Agric. Res. 2016, 14, e1202. [CrossRef]

83. Millán, S.; Casadesús, J.; Campillo, C.; Moñino, M.J.; Prieto, M.H. Using soil moisture sensors for automated irrigation scheduling in a plum crop. Water 2019, 11, 2061. [CrossRef]

84. Domínguez-Niño, J.M.; Oliver-Manera, J.; Girona, J.; Casadesús, J. Differential irrigation scheduling by an automated algorithm of water balance tuned by capacitance-type soil moisture sensors. Agric. Water Manag. 2020, 228, 105880. [CrossRef]

85. Martínez-Gimeno, M.A.; Jiménez-Bello, M.A.; Lidón, A.; Manzano, J.; Badal, E.; Pérez-Pérez, J.G.; Bonet, L.; Intrigliolo, D.S.; Esteban, A. Mandarin irrigation scheduling by means of frequency domain reflectometry soil moisture monitoring. Agric. Water Manag. 2020, 235, 106151. [CrossRef] 
86. Millán, S.; Campillo, C.; Casadesús, J.; Pérez-Rodríguez, J.M.; Prieto, M.H. Automatic irrigation scheduling on a hedgerow olive orchard using an algorithm of water balance readjusted with soil moisture sensors. Sensors 2020, 20, 2526. [CrossRef] [PubMed]

87. Selvaraj, J.D.F.; Paul, P.M.; Jingle, I.D.J. Automatic wireless water management system (AWWMS) for smart vineyard irrigation using IoT technology. Int. J. Oceans Oceanog. 2019, 13, 211-218.

88. Poblete, T.; Ortega-Farías, S.; Ryu, D. Automatic coregistration algorithm to remove canopy shaded pixels in UAV-borne thermal images to improve the estimation of crop water stress index of a drip-irrigated Cabernet Sauvignon vineyard. Sensors 2018, 18, 397. [CrossRef] [PubMed]

89. Liang, S.; Li, X.; Wang, J. Advanced Remote Sensing: Terrestrial Information Extraction and Applications; Academic Press: Amsterdam, The Netherlands, 2012. [CrossRef]

90. Zhang, B.; Kang, S.; Li, F.; Zhang, L. Comparison of three evapotranspiration models to Bowen ratio-energy balance method for a vineyard in an arid desert region of northwest China. Agric. Forest Meteorol. 2008, 148, 1629-1640. [CrossRef]

91. Jiao, L.; Ding, R.; Kang, S.; Du, T.; Tong, L.; Li, S. A comparison of energy partitioning and evapotranspiration over closed maize and sparse grapevine canopies in northwest China. Agric. Water Manag. 2018, 203, 251-260. [CrossRef]

92. Rodriguez-Lovelle, B.; Trambouze, W.; Jacquet, O. Évaluation de l'état de croissance végétative de la vigne par la "méthode des apex". Prog. Agric. Vitic. 2009, 126, 77-88.

93. Keller, M. The Science of Grapevines, 2nd ed.; Academic Press: Cambridge, MA, USA, 2015; 522p.

94. Scholander, P.F.; Bradstreet, E.D.; Hemmingsen, E.A.; Hammel, H.T. Sap pressure in vascular plants. Science 1965, 148, 339-346. [CrossRef]

95. Choné, X.; van Leeuwen, C.; Dubourdieu, D.; Gaudillère, J.-P. Stem water potential is a sensitive indicator of grapevine water status. Ann. Bot. 2001, 87, 477-483. [CrossRef]

96. Santesteban, L.G.; Miranda, C.; Marín, D.; Sesma, B.; Intrigliolo, D.S.; Mirás-Avalos, J.M.; Escalona, J.M.; Montoro, A.; de Herralde, F.; Baeza, P.; et al. Discrimination ability of leaf and stem water potential at different times of the day through a meta-analysis in grapevine (Vitis vinifera L.). Agric. Water Manag. 2019, 221, 202-210. [CrossRef]

97. Levin, A. Re-evaluating pressure chamber methods of water status determination in field-grown grapevine (Vitis spp.). Agric. Water Manag. 2019, 221, 422-429. [CrossRef]

98. Améglio, T.; Archer, P.; Cohen, M.; Valancogne, C.; Daudet, F.A.; Dayan, S.; Cruiziat, P. Significance and limits in the use of predawn leaf water potential for tree irrigation. Plant. Soil 1999, 207, 155-167. [CrossRef]

99. Hochberg, U.; Rockwell, F.E.; Holbrook, N.M.; Cochard, H. Iso/anisohydry: A plant-environment interaction rather than a simple hydraulic trait. Trends Plant. Sci. 2018, 23, 112-120. [CrossRef]

100. Blanco-Cipollone, F.; Lourenço, S.; Silvestre, J.; Conceição, N.; Moñino, M.J.; Vivas, A.; Ferreira, M.I. Plant water status indicators for irrigation scheduling associated with iso- and anisohydric behavior: Vine and plum trees. Horticulturae 2017, 3, 47. [CrossRef]

101. Dayer, S.; Herrera, J.C.; Dai, Z.; Burlett, R.; Lamarque, L.J.; Delzon, S.; Bortolani, G.; Cochard, H.; Gambetta, G.A. Nightitme transpiration represents a negligible part of water loss and does not increase the risk of water stress in grapevine. Plant. Cell Environ. 2021, 44, 387-398. [CrossRef]

102. Girona, J.; Mata, M.; del Campo, J.; Arbonés, A.; Bartra, E.; Marsal, J. The use of midday leaf water potential for scheduling deficit irrigation in vineyards. Irrig. Sci. 2006, 24, 115-127. [CrossRef]

103. Cole, J.; Pagay, V. Usefulness of early morning stem water potential as a sensitive indicator of water status of deficit-irrigated grapevines (Vitis vinifera L.). Sci. Hortic. 2015, 191, 10-14. [CrossRef]

104. Williams, L.E. Leaf water potential of sunlit and/or shaded grapevine leaves are sensitive alternatives to stem water potential. J. Int. Sci. Vigne Vin 2012, 46, 207-219. [CrossRef]

105. Williams, L.E. Physiological tools to assess vine water status for use in vineyard irrigation management: Review and update. Acta Hortic. 2017, 1157, 151-166. [CrossRef]

106. Ojeda, H. Irrigation qualitative de précision de la vigne. Progrès Agric. Vitic. 2007, 127, 133-141.

107. Martínez, E.M.; Cancela, J.J.; Cuesta, T.S.; Neira, X.X. Review. Use of psychrometers in field measurements of plant material: Accuracy and handling difficulties. Span. J. Agric. Res. 2011, 9, 313-328. [CrossRef]

108. Cancela, J.J.; Dafonte, J.J.; Martínez, E.M.; Cuesta, T.S.; Neira, X.X. Assessment of a water activity meter for rapid measurements of soil water potential. Biosyst. Eng. 2006, 94, 285-295. [CrossRef]

109. Martínez, E.M.; Rey, B.J.; Fandiño, M.; Cancela, J.J. Comparison of two techniques for measuring leaf water potential in Vitis vinifera var. Albariño. Ciência Téc. Vitiv. 2013, 28, 29-41.

110. Van Leeuwen, C.; Trégoat, O.; Choné, X.; Bois, B.; Pernet, D.; Gaudillère, J.P. Vine water status is a key factor in a grapevine ripening and vintage quality for red Bordeaux wine. How can it be assessed for vineyard management purposes? J. Int. Sci. Vigne Vin 2009, 43, 121-134. [CrossRef]

111. García-Tejera, O.; López-Bernal, Á.; Orgaz, F.; Testi, L.; Villalobos, F. The pitfalls of wáter potential for irrigation scheduling. Agric. Water Manag. 2021, 243, 106522. [CrossRef]

112. Craig, H. The geochemistry of the stable carbon isotopes. Geochim. Cosmochim. Acta 1953, 3, 53-92. [CrossRef]

113. Farquhar, G.D.; von Caemmerer, S.; Berry, J.A. A biochemical model of photosynthetic $\mathrm{CO}_{2}$ assimilation in leaves of $\mathrm{C} 3$ species. Planta 1980, 149, 78-90. [CrossRef] [PubMed]

114. Gaudillère, J.-P.; van Leeuwen, C.; Ollat, N. Carbon isotope composition of sugars in grapevine, an integrated indicator of vineyard water status. J. Exp. Bot. 2002, 53, 757-763. [CrossRef] [PubMed] 
115. Santesteban, L.G.; Miranda, C.; Barbarin, I.; Royo, J.B. Application of the measurement of the natural abundance of stable isotopes in viticulture: A review. Aus. J. Grape Wine Res. 2015, 21, 157-167. [CrossRef]

116. Herrero-Langreo, A.; Tisseyre, B.; Goutouly, J.-P.; Scholasch, T.; van Leeuwen, C. Mapping grapevine (Vitis vinifera L.) water status during the season using carbon isotope ratio $\left({ }^{13} \mathrm{C}\right)$ as ancillary data. Am. J. Enol. Vitic. 2013, 64, 307-315. [CrossRef]

117. Van Leeuwen, C.; Roby, J.-P.; de Rességuier, L. Soil-related terroir factors: A review. OENO One 2018, 52, 173-188. [CrossRef]

118. Coulouma, G.; Prevot, L.; Lagacherie, P. Carbon isotope discrimination as a surrogate for soil available capacity in rainfed areas: A study in the Languedoc vineyard plain. Geoderma 2020, 362, 114121. [CrossRef]

119. Spangenberg, J.E.; Schweizer, M.; Zufferey, V. Shifts in carbon and nitrogen stable isotope composition and epicuticular lipids in leaves reflect early water-stress in vineyards. Sci. Total Environ. 2020, 739, 140343. [CrossRef]

120. Cifre, J.; Bota, J.; Escalona, J.M.; Medrano, H.; Flexas, J. Physiological tools for irrigation scheduling in grapevine (Vitis vinifera L.). An open gate to improve water-use efficiency? Agric. Ecosyst. Environ. 2005, 106, 159-170. [CrossRef]

121. Urban, L.; Aarrouf, J.; Bidel, L.P.R. Assessing the effects of water deficit on photosynthesis using parameters derived from measurements of leaf gas exchange and of chlorophyll a fluorescence. Front. Plant. Sci. 2017, 8, 2068. [CrossRef]

122. Schultz, H.R. Differences in hydraulic architecture account for near-isohydric and anisohydric behaviour of two field-grown Vitis vinifera L. cultivars during drought. Plant. Cell Environ. 2003, 26, 1393-1405. [CrossRef]

123. Chaves, M.M.; Costa, J.M.; Zarrouk, O.; Pinheiro, C.; Lopes, C.M.; Pereira, J.S. Controlling stomatal aperture in semi-arid regions-The dilemma of saving water or being cool? Plant. Sci. 2016, 251, 54-64. [CrossRef]

124. Hernández-Santana, V.; Fernández, J.E.; Rodríguez-Domínguez, C.M.; Romero, R.; Díaz-Espejo, A. The dynamics of radial sap flux density reflects changes in stomatal conductance in response to soil and air water deficit. Agric. Forest Meteorol. 2016, 218-219, 92-101. [CrossRef]

125. Romero, P.; Fernández-Fernández, J.I.; Martínez-Cutillas, A. Physiological thresholds for efficient regulated deficit-irrigation management in winegrapes grown under semiarid conditions. Am. J. Enol. Vitic. 2010, 61, 300-312.

126. Granier, A. Une nouvelle méthode pour la mesure du flux de sève brute dans le tronc des arbres. Ann. Sci. For. 1985, 42, 193-200. [CrossRef]

127. Lascano, R.J.; Goebel, T.S.; Booker, J.; Baker, J.T.; Gitz III, D.C. The stem heat balance method to measure transpiration: Evaluation of a new sensor. Agric. Sci. 2016, 7, 604-620. [CrossRef]

128. Ferreira, M.I.; Silvestre, J.; Conceição, N.; Malheiro, A.C. Crop and stress coefficients in rainfed and deficit irrigation vineyards using sap flow techniques. Irrig. Sci. 2012, 30, 433-447. [CrossRef]

129. Yunusa, I.A.M.; Walker, R.R.; Loveys, B.R.; Blackmore, D.H. Determination of transpiration in irrigated grapevines: Comparison of the heat-pulse technique with gravimetric and micrometeorological methods. Irrig. Sci. 2000, 20, 1-8. [CrossRef]

130. Malheiro, A.C.; Pires, M.; Conceição, N.; Claro, A.M.; Dinis, L.T.; Moutinho-Pereira, J. Linking sap flow and trunk diameter measurements to assess water dynamics of Touriga-Nacional grapevines trained in cordon and guyot systems. Agriculture 2020, 10, 315. [CrossRef]

131. Braun, P.; Schmid, J. Sap flow measurements in grapevines (Vitis vinifera L.). 1. Stem morphology and use of the heat balance method. Plant. Soil 1999, 215, 39-45. [CrossRef]

132. Braun, P.; Schmid, J. Sap flow measurements in grapevines (Vitis vinifera L.). 2. Granier measurements. Plant. Soil 1999, $215,47-55$. [CrossRef]

133. Fernández, J.E.; Cuevas, M.V. Irrigation scheduling from stem diameter variations: A review. Agr. Forest Meteorol. 2010, 150, 135-151. [CrossRef]

134. Montoro, A.; Fereres, E.; López-Urrea, R.; Mañas, F.; López-Fuster, P. Sensitivity of trunk diameter fluctuations in Vitis vinifera L. Tempranillo and Cabernet Sauvignon cultivars. Am. J. Enol. Vitic. 2012, 63, 85-93. [CrossRef]

135. Intrigliolo, D.S.; Castel, J.R. Crop load affects maximum daily trunk shrinkage of plum trees. Tree Physiol. 2007, 27, 89-96. [CrossRef]

136. Mirás-Avalos, J.M.; Pérez-Sarmiento, F.; Alcobendas, R.; Alarcón, J.J.; Mounzer, O.; Nicolás, E. Maximum daily trunk shrinkage for estimating water needs and scheduling regulated deficit irrigation in peach trees. Irrig. Sci. 2017, 35, 69-82. [CrossRef]

137. Intrigliolo, D.S.; Castel, J.R. Evaluation of grapevine water status from trunk diameter variations. Irrig. Sci. 2007, 26, 49-59. [CrossRef]

138. Rodríguez-Domínguez, C.M.; Buckley, T.N.; Egea, G.; de Cires, A.; Hernández-Santana, V.; Martorell, S.; Díaz-Espejo, A. Most stomatal closure in woody species under moderate drought can be explained by stomatal response to leaf turgor. Plant. Cell Environ. 2016, 39, 2014-2016. [CrossRef]

139. Zimmermann, U.; Bitter, R.; Ribeiro-Marchiori, P.E.; Rüger, S.; Ehrenberger, W.; Sukhorukov, V.L.; Schüttler, A.; VasconcelosRibeiro, R. A non-invasive plant-based probe for continuous monitoring of water stress in real time: A new tool for irrigation scheduling and deeper insight into drought and salinity stress physiology. Theor. Exp. Plant. Physiol. 2013, 25, 2-11. [CrossRef]

140. Rüger, S.; Netzer, Y.; Westhoff, M.; Zimmermann, D.; Reuss, R.; Ovadya, S.; Gessner, P.; Zimmermann, G.; Schwartz, A.; Zimmermann, U. Remote monitoring of leaf turgor pressure of grapevines subjected to different irrigation treatments using the leaf patch clamp pressure probe. Aust. J. Grape Wine Res. 2010, 16, 405-412. [CrossRef]

141. Berdeja, M.; Nicolas, P.; Kappel, C.; Dai, Z.; Hilbert, G.; Peccoux, A.; Lafontaine, M.; Ollat, N.; Gomes, E.; Delrot, S. Water limitation and rootstock genotype interact to alter grape berry metabolism through transcriptome reprogramming. Hortic. Res. 2015, 2, 15012. [CrossRef] 
142. Bianchi, D.; Grossi, D.; Tincani, D.; Lorenzo, G.; Brancadoro, L.; Rustioni, L. Multi-parameter characterization of water stress tolerance in Vitis hybrids for new rootstock selection. Plant. Physiol. Biochem. 2018, 132, 333-340. [CrossRef] [PubMed]

143. Romero, P.; Botía, P.; Navarro, J.M. Selecting rootstocks to improve vine performance and vineyard sustainability in deficit irrigated Monastrell grapevines under semiarid conditions. Agric. Water Manag. 2018, 209, 73-93. [CrossRef]

144. Chaves, M.; Santos, T.; Souza, C.; Ortuño, M.; Rodrigues, M.; Lopes, C.; Maroco, J.; Pereira, J. Deficit irrigation in grapevine improves water-use efficiency while controlling vigour and production quality. Ann. Appl. Biol. 2007, 150, 237-252. [CrossRef]

145. Pou, A.; Medrano, H.; Tomàs, M.; Martorell, S.; Ribas-Carbó, M.; Felxas, J. Anisohydric behaviour in grapevines results in better performance under moderate water stress and recovery than isohydric behavior. Plant. Soil 2012, 359, 335-349. [CrossRef]

146. Zhang, L.; Marguerit, E.; Rossdeutsch, L.; Ollat, N.; Gambetta, G.A. The influence of grapevine rootstocks on scion growth and drought resistance. Theor. Exp. Plant. Physiol. 2016, 28, 143-157. [CrossRef]

147. Bota, J.; Tomás, M.; Flexas, J.; Medrano, H.; Escalona, J.M. Differences among grapevine cultivars in their stomatal behavior and water use efficiency under progressive water stress. Agric. Water Manag. 2016, 164, 91-99. [CrossRef]

148. Fredrikson, L.; Skinkis, P.A.; Peachey, E. Cover crop and floor management affect weed coverage and density in an establishing Oregon vineyard. HortTechnology 2011, 21, 208-216. [CrossRef]

149. Mirás-Avalos, J.M.; Ramírez-Cuesta, J.M.; Fandiño, M.; Cancela, J.J.; Intrigliolo, D.S. Agronomic practices for reducing soil erosion in hillside vineyards under Atlantic climatic conditions (Galicia, Spain). Soil Syst. 2020, 4, 19. [CrossRef]

150. Guerra, B.; Steenwerth, K. Influence of floor management technique on grapevine growth, disease pressure, and juice and wine composition: A review. Am. J. Enol. Vitic. 2012, 63, 149-164. [CrossRef]

151. Prosdocimi, M.; Cerdà, A.; Tarolli, P. Soil water erosion on Mediterranean vineyards: A review. Catena 2016, 141, 1-21. [CrossRef]

152. Ferrara, G.; Fracchiolla, M.; Al Chami, Z.; Camposero, S.; Lasorella, C.; Pacifico, A.; Aly, A.; Montemurro, P. Effects of mulching material son soils and performance of cv. Nero di Troia grapevines in the Puglia Region, Southeastern Italy. Am. J. Enol. Vitic. 2012, 63, 269-276. [CrossRef]

153. Montanaro, G.; Xiloyannis, C.; Nuzzo, V.; Dichio, B. Orchard management, soil organic carbon and ecosystem services in Mediterrranean fruit tree crops. Sci. Hortic. 2017, 217, 92-101. [CrossRef]

154. López-Urrea, R.; Sánchez, J.M.; Montoro, A.; Mañas, F.; Intrigliolo, D.S. Effect of using pruning waste as an organic mulching on a drip-irrigated vineyard evapotranspiration under a semi-arid climate. Agric. Forest Meteorol. 2020, 291, 108064. [CrossRef]

155. Buesa, I.; Mirás-Avalos, J.M.; De Paz, J.M.; Visconti, F.; Sanz, F.; Yeves, A.; Guerra, D.; Intrigliolo, D.S. Soil management in semi-arid vineyards: Combined effects of organic mulching and no-tillage under different water regimes. Eur. J. Agron. 2021, 123, 126198. [CrossRef]

156. Ben-Salem, N.; Álvarez, S.; López-Vicente, M. Soil and water conservation in rainfed vineyards with common sainfoin and spontaneous vegetation under different ground conditions. Water 2018, 10, 1058. [CrossRef]

157. Virto, I.; Imaz, M.J.; Fernández-Ugalde, O.; Urrutia, I.; Enrique, A.; Bescansa, P. Soil quality evaluation following the implementation of permanent cover crops in semiarid vineyards. Organic matter, physical and biological soil properties. Span. J. Agric. Res. 2012, 10, 1121-1132. [CrossRef]

158. Morlat, R.; Jacquet, A. Grapevine root system and soil characteristics in a vineyard maintained long-term with or without interrow sward. Am. J. Enol. Vitic. 2003, 54, 1-7.

159. Monteiro, A.; Lopes, C.M. Influence of cover crop on water use and performance of vineyard in Mediterranean Portugal. Agric. Ecosys. Environ. 2007, 121, 336-342. [CrossRef]

160. Celette, F.; Gaudin, R.; Gary, C. Spatial and temporal changes to the water regime of a Mediterranean vineyard due to the adoption of cover cropping. Eur. J. Agron. 2008, 29, 153-162. [CrossRef]

161. Linares Torres, R.; de la Fuente Lloreda, M.; Junquera-González, P.; Lissarrague García-Gutiérrez, R.; Baeza Trujillo, P. Effect of soil management strategies on the characteristics of the grapevine root system in irrigated vineyards under semi-arid conditions. Aus. J. Grape Wine Res. 2018, 24, 439-449. [CrossRef]

162. Trigo-Córdoba, E.; Bouzas-Cid, Y.; Orriols-Fernández, I.; Díaz-Losada, E.; Mirás-Avalos, J.M. Influence of cover crop treatments on the performance of a vineyard in a humid region. Span. J. Agric. Res. 2015, 13, e0907. [CrossRef]

163. Coniberti, A.; Ferrari, V.; Disegna, E.; Garcia Petillo, M.; Lakso, A.N. Under-trellis cover crop and planting density to achieve vine balance in a humid climate. Sci. Hortic. 2018, 227, 65-74. [CrossRef]

164. Coniberti, A.; Ferrari, V.; Disegna, E.; Dellacassa, E.; Lakso, A.N. Under-trellis cover crop and deficit irrigation to regulate water availability and enhance Tannat wine sensory attributes in a humid climate. Sci. Hortic. 2018, 235, 244-252. [CrossRef]

165. Daane, K.M.; Hogg, B.N.; Wilson, H.; Yokota, G.Y. Native grass ground covers provide multiple ecosystem services in Californian vineyards. J. Appl. Ecol. 2018, 55, 2473-2483. [CrossRef]

166. Santesteban, L.G.; Miranda, C.; Urrestarazu, J.; Loidi, M.; Royo, J.B. Severe trimming and enhanced competition of laterals as a tool to delay ripening in Tempranillo vineyards under semiarid conditions. OENO One 2017, 51, 191-203. [CrossRef]

167. Reynolds, A.G.; Vanden-Heuvel, J.E. Influence of grapevine training systems on vine growth and fruit composition: A review. Am. J. Enol. Vitic. 2009, 60, 251-268.

168. Campos, I.; Neale, C.M.U.; Calera, A. Is row orientation a determinant factor for radiation interception in row vineyards? Aus. J. Grape Wine Res. 2017, 23, 77-86. [CrossRef]

169. Hunter, J.J.; Volschenk, C.G.; Zorer, R. Vineyard row orientation of Vitis vinifera L. cv. Shiraz/101-14 Mgt: Climatic profiles and vine physiological status. Agric. Forest Meteorol. 2016, 228-229, 104-119. [CrossRef] 
170. Buesa, I.; Mirás-Avalos, J.M.; Intrigliolo, D.S. Row orientation effects on potted-vines performance and water-use efficiency. Agric. Forest Meteorol. 2020, 294, 108148. [CrossRef]

171. Buesa, I.; Ballester, C.; Mirás-Avalos, J.M.; Intrigliolo, D.S. Effects of leaning grapevine canopy to the West on water use efficiency and yield under Mediterranean conditions. Agric. Forest Meteorol. 2020, 295, 108166. [CrossRef]

172. van Leeuwen, C.; Pieri, P.; Gowdy, M.; Ollat, N.; Roby, J.P. Reduced density is an environmental friendly and cost effective solution to increase resilience to drought in vineyards in a context of climate change. OENO One 2019, 53, 129-146. [CrossRef]

173. Anzanello, R.; Souza, P.V.D.; Coelho, P.F. Use of Winter pruning and Green pruning for obtaining two harvestes by vegetative cycle of three vine cultivars. Rev. Bras. Fruitc. 2010, 32, 196-203. [CrossRef]

174. Bravdo, B.; Hepner, Y.; Loinger, S.; Cohen, S.; Tabacman, H. Effect of irrigation on growth, yield and wine quality of Cabernet Sauvignon. Am. J. Enol. Vitic. 1985, 36, 132-139.

175. Nadal, M.; Arola, L. Effects of limited irrigation on the composition of must and wine of Cabernet-Sauvignon under semi-arid conditions. Vitis 1995, 34, 151-154. [CrossRef]

176. McCarthy, M.G. Developmental variation in sensitivity of Vitis vinifera L. (Shiraz) berries to soil water deficit. Aus. J. Grape Wine Res. 2000, 6, 136-140. [CrossRef]

177. Keller, M. Deficit irrigation and vine mineral nutrition. Am. J. Enol. Vitic. 2005, 56, 267-283.

178. Williams, L.E. Interaction of applied water amounts and leaf removal in the fruiting zone on grapevine water relations and productivity of Merlot. Irrig. Sci. 2012, 30, 363-375. [CrossRef]

179. Naor, A.; Bravdo, B.; Hepner, Y. Effect of post-véraison irrigation level on Sauvignon blanc yield, juice quality and water relations. S. Afr. J. Enol. Vitic. 1993, 14, 19-25. [CrossRef]

180. Wenter, A.; Zanotelli, D.; Montagnari, L.; Tagliavini, M.; Andreotti, C. Effect of different timings and intensities of water stress on yield and berry composition of grapevine (cv. Sauvignon blanc) in a mountain environment. Sci. Hortic. 2018, 236, 137-145. [CrossRef]

181. Basile, B.; Girona, J.; Behboudian, M.H.; Mata, M.; Rosello, J.; Ferré, M.; Marsal, J. Responses of “Chardonnay” to deficit irrigation applied at different phenological stages: Vine growth, must composition, and wine quality. Irrig. Sci. 2012, 30, 397-406. [CrossRef]

182. Prats-Llinàs, M.T.; Bellvert, J.; Mata, M.; Marsal, J.; Girona, J. Post-harvest regulated deficit irrigation in Chardonnay did not reduce yield but at long-term, it could affect berry composition. Agronomy 2019, 9, 328. [CrossRef]

183. Montoro, A.; Valdés, E.; Vilanova, M.; Moreno, D.; Serrano, K.; Salinas, R.; Mañas, F.; Sánchez-Felipe, L.; López-Urrea, R. Different behaviour of two grapevine cultivars under similar irrigation management. Acta Hortic. 2017, 1150, 477-487. [CrossRef]

184. Buesa, I.; Pérez, D.; Castel, J.; Intrigliolo, D.S.; Castel, J.R. Effect of deficit irrigation on vine performance and grape composition of Vitis vinifera L. cv. Muscat of Alexandria. Aus. J. Grape Wine Res. 2017, 23, 251-259. [CrossRef]

185. Zufferey, V.; Verdenal, T.; Dienes, A.; Belcher, S.; Lorenzini, F.; Koestel, C.; Blackford, M.; Bourdin, G.; Gindro, K.; Spangenberg, J.E.; et al. The influence of vine water regime on the leaf gas exchange, berry composition and wine quality of Arvine grapes in Switzerland. OENO One 2020, 54, 553-568. [CrossRef]

186. Zúñiga, M.; Ortega-Farias, S.; Fuentes, S.; Riveros-Burgos, C.; Poblete-Echeverría, C. Effects of three irrigation strategies on gas exchange relationships, plant water status, yield components and water productivity of grafted Cerménère grapevines. Front. Plant. Sci. 2018, 9, 992. [CrossRef]

187. Trigo-Córdoba, E.; Bouzas-Cid, Y.; Orriols-Fernández, I.; Mirás-Avalos, J.M. Effects of deficit irrigation on the performance of grapevine (Vitis vinifera L.) cv. 'Godello' and 'Treixadura' in Ribeiro, NW Spain. Agric. Water Manag. 2015, 161, 20-30. [CrossRef]

188. Larani, V.; Palliotti, A.; Sabbatini, P.; Stanley Howell, G.; Silvestroni, O. Optimizing deficit irrigation strategies to manage vine performance and fruit composition of field-grown 'Sangiovese' (Vitis vinifera L.) grapevines. Sci. Hortic. 2014, 179, $239-247$. [CrossRef]

189. Vilanova, M.; Rodríguez-Nogales, J.M.; Vila-Crespo, J.; Yuste, J. Influence of water regime on yield components, must composition and wine volatile compounds of Vitis vinifera cv. Verdejo. Aus. J. Grape Wine Res. 2019, 25, 83-91. [CrossRef]

190. Stoll, M.; Loveys, B.; Dry, P. Hormonal changes induced by partial rootzone drying of irrigated grapevine. J. Exp. Bot. 2000, 51, 1627-1634. [CrossRef]

191. Dry, P.R.; Loveys, B.R.; McCarthy, M.G.; Stoll, M. Strategic irrigation management in Australian vineyards. J. Int. Sci. Vigne Vin 2001, 35, 129-139. [CrossRef]

192. dos Santos, T.P.; Lopes, C.M.; Rodrigues, M.L.; de Souza, C.; Ricardo-da-Silva, J.M.; Maroco, J.P.; Pereira, J.S.; Chaves, M.M. Effects of deficit irrigation strategies on cluster microclimate for improving fruit composition of Moscatel field-grown grapevines. Sci. Hortic. 2007, 112, 321-330. [CrossRef]

193. Du, T.; Kang, S.; Zhang, J.; Li, F.; Yan, B. Water use efficiency and fruit quality of table grape under alternate partial root-zone drip irrigation. Agric. Water Manag. 2008, 95, 659-668. [CrossRef]

194. Gil, P.M.; Lobos, P.; Durán, K.; Olguín, J.; Cea, D.; Schaffer, B. Partial root-zone drying irrigation, shading, or mulching effects on water savings, productivity and quality of 'Syrah' grapevines. Sci. Hortic. 2018, 240, 478-483. [CrossRef]

195. Bravdo, B.; Naor, A.; Zahavi, T.; Gal, Y. The effect of water stress applied alternately to part of the wetting zone along the season (PRD—Partial Rootzone Drying) on wine quality, yield and water relations of red wine grapes. Acta Hortic. 2004, 664, 101-109. [CrossRef] 
196. Marsal, J.; Mata, M.; del Campo, J.; Arbones, A.; Vallverdú, X.; Girona, J.; Olivo, N. Evaluation of partial root-zone drying for potential field use as a deficit irrigation technique in commercial vineyards according to two different pipeline layouts. Irrig. Sci. 2008, 26, 347-356. [CrossRef]

197. Intrigliolo, D.S.; Castel, J.R. Response of Vitis vinifera cv. 'Tempranillo' to partial rootzone drying in the field: Water relations, growth, yield and fruit and wine quality. Agric. Water Manag. 2009, 96, 282-292. [CrossRef]

198. Ma, X.; Sanguinet, K.A.; Jacoby, P.W. Direct root-zone irrigation outperforms surface drip irrigation for grape yield and crop water use efficiency while restricting root growth. Agric. Water Manag. 2020, 231, 105993. [CrossRef]

199. Uriarte, D.; Intrigliolo, D.S.; Mancha, L.A.; Valdés, E.; Gamero, E.; Prieto, M.H. Combined effects of irrigation regime and crop load on 'Tempranillo' grape composition. Agric. Water Manag. 2016, 165, 97-107. [CrossRef]

200. Romić, D.; Karoglan Kontić, J.; Preiner, D.; Romić, M.; Lazarević, B.; Maletić, E.; Ondrašek, G.; Andabaka, Ž.; Bakić Begić, H.; Bubalo Kovačić, M.; et al. Performance of grapevine grown on reclaimed Mediterranean karst land: Appearance and duration of high temperature events and effects of irrigation. Agric. Water Manag. 2020, 236, 106166. [CrossRef]

201. Intrigliolo, D.S.; Lizama, V.; García-Esparza, M.J.; Abrisqueta, I.; Álvarez, I. Effects of post-veraison irrigation regime on Cabernet Sauvignon grapevines in Valencia, Spain: Yield and grape composition. Agric. Water Manag. 2016, 170, 110-119. [CrossRef]

202. Munitz, S.; Schwartz, A.; Netzer, Y. Water consumption, crop coefficient and leaf area relations of a Vitis vinifera cv. 'Cabernet Sauvignon' vineyard. Agric. Water Manag. 2019, 219, 86-94. [CrossRef]

203. Wang, R.; Yan, P.; Sun, Q.; Su, B.; Zhang, J. Effects of regulated deficit irrigation on the growth and berry composition of Cabernet Sauvignon in Ningxia. Int. J. Agric. Biol. Eng. 2019, 12, 102-109. [CrossRef]

204. Naulleau, A.; Gary, C.; Prévot, L.; Hossard, L. Evaluating strategies for adaptation to climate change in grapevine production-A systematic review. Front. Plant. Sci. 2021, 11, 607859. [CrossRef] [PubMed]

205. Prats-Llinàs, M.T.; García-Tejera, O.; Marsal, J.; Girona, J. Water stress during the post-harvest period affects new root formation but not starch concentration and content in Chardonnay grapevine (Vitis vinifera L.) perennial organs. Sci. Hortic. 2019, 249, 461-470. [CrossRef]

206. Lamm, F.R.; Bordovsky, J.P.; Schwankl, L.J.; Grabow, G.L.; Enciso-Medina, J.; Peters, R.T.; Colaizzi, P.D.; Trooien, T.P.; Porter, D.O. Subsurface drip irrigation: Status of the technology in 2010. Trans. ASABE 2012, 55, 483-491. [CrossRef]

207. Ma, X.; Sanguinet, K.A.; Jacoby, P.W. Performance of direct root-zone deficit irrigation on Vitis vinifera L. cv. Cabernet Sauvignon production and water use efficiency in semi-arid southcentral Washington. Agric. Water Manag. 2019, 221, 47-57. [CrossRef]

208. Pisciotta, A.; Di Lorenzo, R.; Santalucia, G.; Barbagallo, M.G. Response of grapevine (Cabernet Sauvignon cv) to above ground and subsurface drip irrigation under arid conditions. Agric. Water Manag. 2018, 197, 122-131. [CrossRef]

209. Robinson, A.L.; Boss, P.K.; Solomon, P.S.; Trengove, R.D.; Heymann, H.; Ebeler, S.E. Origins of grape and wine aroma. Part 2. Chemical and sensory analysis. Am. J. Enol. Vitic. 2014, 65, 25-42. [CrossRef]

210. Deluc, L.G.; Qulici, D.R.; Decendit, A.; Grimplet, J.; Wheatley, M.D.; Schlauch, K.A.; Mérillon, J.M.; Cushman, J.C.; Cramer, G.R. Water deficit induces cultivar-specific effects in multiple metabolic pathways affecting important flavor and quality traits throughout grape ripening. BMC Genom. 2009, 10, 212. [CrossRef] [PubMed]

211. Bouzas-Cid, Y.; Díaz-Losada, E.; Trigo-Córdoba, E.; Falqué, E.; Orriols, I.; Garde-Cerdán, T.; Mirás-Avalos, J.M. Effects of irrigation over three years on the amino acid composition of Albariño (Vitis vinifera L.) musts and wines in two different terroirs. Sci. Hortic. 2018, 227, 313-325. [CrossRef]

212. Mirás-Avalos, J.M.; Bouzas-Cid, Y.; Trigo-Córdoba, E.; Orriols, I.; Falqué, E. Effects of two different irrigation systems on the amino acid concentrations, volatile composition and sensory profiles of Godello musts and wines. Foods 2019, 8, 135. [CrossRef] [PubMed]

213. Canoura, C.; Kelly, M.T.; Ojeda, H. Effect of irrigation and timing and type of nitrogen application on the biochemical composition of Vitis vinifera L. cv. Chardonnay and Syrah grapeberries. Food Chem. 2018, 241, 171-181. [CrossRef] [PubMed]

214. Wang, J.; Abbey, T.; Kozak, B.; Madilao, L.L.; Tindjau, R.; Del Nin, J.; Castellarin, S.D. Evolution over the growing season of volatile organic compounds in Viognier (Vitis vinifera L.) grapes under three irrigation regimes. Food Res. Int. 2019, $125,108512$. [CrossRef]

215. Mirás-Avalos, J.M.; Bouzas-Cid, Y.; Trigo-Córdoba, E.; Orriols, I.; Falqué, E. Irrigation effects on the volatile composition and sensory profile of Albariño wines from two different terroirs. Eur. Food Res. Technol. 2019, 245, 2157-2171. [CrossRef]

216. Kovalenko, Y.; Tindjau, R.; Madilao, L.L.; Castellarin, S.D. Regulated deficit irrigation strategies affect the terpene accumulation in Gewürztraminer (Vitis vinifera L.) grapes grown in the Okanagan Valley. Food Res. Int. 2021, 341, 128172. [CrossRef] [PubMed]

217. Acevedo-Opazo, C.; Ortega-Farias, S.; Fuentes, S. Effects of grapevine (Vitis vinifera L.) water status on water consumption, vegetative growth and grape quality: An irrigation scheduling application to achieve regulated deficit irrigation. Agric. Water Manag. 2010, 97, 956-964. [CrossRef]

218. Ortuani, B.; Facchi, A.; Mayer, A.; Bianchi, D.; Bianchi, A.; Brancadoro, L. Assessing the effectiveness of variable-rate drip irrigation on water use efficiency in a vineyard in Northern Italy. Water 2019, 11, 1964. [CrossRef]

219. Junquera, P.; Lissarrague, J.R.; Jiménez, L.; Linares, R.; Baeza, P. Long-term effects of different irrigation strategies on yield components, vine vigour, and grape composition in cv. Cabernet-Sauvignon (Vitis vinifera L.). Irrig. Sci. 2012, 30, $351-361$. [CrossRef] 
220. Romero, P.; García García, J.; Fernández-Fernández, J.I.; Gil Muñoz, R.; del Amor Saavedra, F.; Martínez-Cutillas, A. Improving berry and wine quality attributes and vineyard economic efficiency by long-term deficit irrigation practices under semiarid conditions. Sci. Hortic. 2016, 203, 69-85. [CrossRef]

221. Howell, C.L.; Myburgh, P.A.; Conradie, W.J. Comparison of three different fertigation strategies for drip irrigated table grapesPart III. Growth, yield and quality. S. Afr. J. Enol. Vitic. 2013, 34, 21-29. [CrossRef]

222. Fandiño, M.; Vilanova, M.; Caldeira, I.; Silvestre, J.M.; Rey, B.J.; Mirás-Avalos, J.M.; Cancela, J.J. Chemical composition and sensory properties of Albariño wine: Fertigation effects. Food Res. Int. 2020, 137, 109533. [CrossRef] [PubMed]

223. Laurenson, S.; Bolan, N.S.; Smith, E.; McCarthy, M. Review: Use of recycled wastewater for irrigating grapevines. Aus. J. Grape Wine Res. 2012, 18, 1-10. [CrossRef]

224. Dai, Z.W.; Vivin, P.; Barrieu, F.; Ollat, N.; Delrot, S. Physiological and modelling approaches to understand water and carbon fluxes during grape berry growth and quality development: A review. Aus. J. Grape Wine Res. 2010, 16, 70-85. [CrossRef]

225. Cola, G.; Mariani, L.; Salinari, F.; Civardi, S.; Bernizzoni, F.; Gatti, M.; Poni, S. Description and testing of a weather-based model for predicting phenology, canopy development and source-sink balance in Vitis vinifera L. cv. Barbera. Agric. Forest Meteorol. 2014, 184, 117-136. [CrossRef]

226. Louarn, G.; Lecoeur, J.; Lebon, E. A three-dimensional statistical reconstruction model of grapevine (Vitis vinifera) simulating canopy structure variability within and between cultivar/training system pairs. Ann. Bot. 2008, 101, 1167-1184. [CrossRef]

227. Dai, Z.W.; Vivin, P.; Robert, T.; Milin, S.; Li, S.H.; Génard, M. Model-based analysis of sugar accumulation in response to source-sink ratio and water supply in grape (Vitis vinifera) berries. Funct. Plant. Biol. 2009, 36, 527-540. [CrossRef]

228. Peccoux, A.; Loveys, B.; Zhu, J.; Gambetta, G.A.; Delrot, S.; Vivin, P.; Schultz, H.R.; Ollat, N.; Dai, Z.W. Dissecting the rootstock control of scion transpiration using model-assisted analyses in grapevine. Tree Physiol. 2018, 38, 1026-1040. [CrossRef] [PubMed]

229. Zhu, J.; Dai, Z.W.; Vivin, P.; Gambetta, G.A.; Henke, M.; Peccoux, A.; Ollat, N.; Delrot, S. A 3-D functional-structural grapevine model that couples the dynamics of water transport with leaf gas exchange. Ann. Bot. 2018, 121, 833-848. [CrossRef] [PubMed]

230. Zhu, J.; Génard, M.; Poni, S.; Gambetta, G.A.; Vivin, P.; Vercambre, G.; Trought, M.C.T.; Ollat, N.; Delrot, S.; Dai, Z.W. Modelling grape growth in relation to whole-plant carbon and water fluxes. J. Exp. Bot. 2019, 70, 2505-2521. [CrossRef]

231. Lebon, E.; Dumas, V.; Pieri, P.; Schultz, H.R. Modelling the seasonal dynamics of the soil water balance of vineyards. Funct. Plant. Biol. 2003, 30, 699-710. [CrossRef] [PubMed]

232. Srivastava, A.; Sahoo, B.; Raghuwanshi, N.S.; Singh, R. Evaluation of variable-infiltration capacity model and MODIS-terra satellite-derived grid-scale evapotranspiration estimates in a River Basin with Tropical Monsoon-Type climatology. J. Irrig. Drain. Eng. 2017, 143, 04017028. [CrossRef]

233. Srivastava, A.; Kumari, N.; Maza, M. Hydrological response to agricultural land use heterogeneity using variable infiltration capacity model. Water Resour. Manag. 2020, 34, 3779-3794. [CrossRef]

234. Bois, B.; Pieri, P.; van Leeuwen, C.; Wald, L.; Huard, F.; Gaudillere, J.P.; Saur, E. Using remotely sensed solar radiation data for reference evapotranspiration estimation at a daily time step. Agric. Forest Meteorol. 2008, 148, 619-630. [CrossRef]

235. Allen, R.G.; Pereira, L.S. Estimating crop coefficients from fraction ground cover and height. Irrig. Sci. 2009, 28, 17-34. [CrossRef]

236. Jafari, M.; Kamali, H.; Keshavarz, A.; Momeni, A. Estimation of evapotranspiration and crop coefficient of drip-irrigated orange trees under a semi-arid climate. Agric. Water Manag. 2021, 248, 106769. [CrossRef]

237. Valdés-Gómez, H.; Celette, F.; García de Cortázar-Atauri, I.; Jara-Rojas, F.; Ortega-Farías, S.; Gary, C. Modelling soil water content and grapevine growth and development with the STICS crop-soil model under two different water management strategies. J. Int Sci. Vigne Vin 2009, 43, 13-28. [CrossRef]

238. Brillante, L.; Bois, B.; Lévêque, J.; Matthieu, O. Variations in soil-water use by grapevine according to plant water status and soil physical-chemical characteristics-A 3D spatio-temporal analysis. Eur. J. Agron. 2016, 77, 122-135. [CrossRef]

239. Bois, B.; Pauthier, B.; Brillante, L.; Mathieu, O.; Leveque, J.; van Leeuwen, C.; Castel, T.; Richard, Y. Sensitivity of grapevine soil-water balance to rainfall spatial variability at local scale level. Front. Environ. Sci. 2020, 8, 110. [CrossRef]

240. Roux, S.; Gaudin, R.; Tisseyre, B. Why does spatial extrapolation of the vine water status make sense? Insights from a modelling approach. Agric. Water Manag. 2019, 217, 255-264. [CrossRef]

241. Suter, B.; Triolo, R.; Pernet, D.; Dai, Z.W.; van Leeuwen, C. Modeling stem water potential by separating the effects of soil water availability and climatic conditions on water status in grapevine (Vitis vinifera L.). Front. Plant. Sci. 2019, 10, 1485. [CrossRef]

242. Souto, C.; Lagos, O.; Holzapfel, E.; Lal Maskey, H.; Wunderlich, L.; Shapiro, K.; Marino, G.; Snyder, R.; Zaccaria, D. A modified surface energy balance to estimate crop transpiration and soil evaporation in micro-irrigated orchards. Water 2019, $11,1747$. [CrossRef]

243. Fuentes, S.; Tongson, E.; Torrico, D.D.; Gonzalez Viejo, C. Modeling Pinot Noir aroma profiles based on weather and water management information using machine learning algorithms: A vertical vintage analysis using artificial intelligence. Foods 2020, 9, 33. [CrossRef]

244. Brevik, E.C.; Calzolari, C.; Miller, B.A.; Pereira, P.; Kabala, C.; Baumgarten, A.; Jordán, A. Soil mapping, classification, and pedologic modeling: History and future directions. Geoderma 2016, 264, 256-274. [CrossRef]

245. Cancela, J.J.; Fandiño, M.; Rey, B.J.; Dafonte, J.; González, X.P. Discrimination of irrigation water management effects in pergola trellis system vineyards using a vegetation and soil index. Agric. Water Manag. 2017, 183, 70-77. [CrossRef]

246. Visconti, F.; De Paz, J.M. A semi-empirical model to predict the EM38 electromagnetic induction measurements of soils from basic ground properties. Eur. J. Soil Sci. 2021. [CrossRef] 
247. Priori, S.; Martini, E.; Andrenelli, M.C.; Magini, S.; Agnelli, A.E.; Bucelli, P.; Biagi, M.; Pellegrini, S.; Constantini, E.A.C. Improving wine quality through harvest zoning and combined use of remote and soil proximal sensing. Soil Sci. Soc. Am. J. 2013, 77, 1338-1348. [CrossRef]

248. Urretavizcaya, I.; Royo, J.B.; Miranda, C.; Tisseyre, B.; Guillaume, S.; Santesteban, L.G. Relevance of sink-size estimation for within-field zone delineation in vineyards. Precis. Agric. 2017, 18, 133-144. [CrossRef]

249. Hall, A. Remote sensing applications for viticultural terroir analysis. Elements 2018, 14, 185-190. [CrossRef]

250. Zśofi, Z.; Tóth, E.; Rusjan, D.; Bálo, B. Terroir aspects of grape quality in a cool climate wine region: Relationship between water déficit, vegetative growth and berry sugar concentration. Sci. Hortic. 2011, 127, 494-499. [CrossRef]

251. Jones, H.G.; Grant, O.M. Remote sensing and other imaging technologies to monitor grapevine performance. In Grapevines in a Changing Environment: A Molecular and Ecophysical Perspective; Géros, H., Chaves, M.M., Gil, H.M., Delrot, S., Eds.; John Wiley \& Sons: New York, NY, USA, 2015; pp. 179-201.

252. Bellvert, J.; Zarco-Tejada, P.J.; Girona, J.; Fereres, E. Mapping crop water stress index in a "Pinot-noir" vineyard: Comparing ground measurements with thermal remote sensing imagery from an unmanned aerial vehicle. Precis. Agric. 2014, 15, 361-376. [CrossRef]

253. Bramley, R.G.V.; Ouzman, J.; Boss, P.K. Variation in vine vigour, grape yield and vineyard soils and topography as indicators of variation in the chemical composition of grapes, wine and wine sensory attributes. Aus. J. Grape Wine Res. 2011, 17, 217-229. [CrossRef]

254. Acevedo-Opazo, C.; Tisseyre, B.; Ojeda, H.; Guillaume, S. Spatial extrapolation of the vine (Vitis vinifera L.) water status: A first step towards a spatial prediction model. Irrig. Sci. 2010, 28, 143-155. [CrossRef]

255. Romero, M.; Luo, Y.; Su, B.; Fuentes, S. Vineyard water status estimation using multispectral imagery from an UAV platform and machine learning algorithms for irrigation scheduling management. Comput. Electron. Agric. 2019, 147, 109-117. [CrossRef]

256. Ohana-Levi, N.; Knipper, K.; Kustas, W.P.; Anderson, M.C.; Netzer, Y.; Gao, F.; Alsina, M.M.; Sanchez, L.A.; Karnieli, A. Using satellite thermal-based evapotranspiration time series for defining management zones and spatial association to local attributes in a vineyard. Remote Sens. 2020, 12, 2436. [CrossRef]

257. Santesteban, L.G.; Di Gennaro, S.F.; Herrero-Langreo, A.; Miranda, C.; Royo, J.B.; Matese, A. High-resolution UAV-based thermal imaging to estimate the instantaneous and seasonal variability of plant water status within a vineyard. Agric. Water Manag. 2017, 183, 49-59. [CrossRef]

258. Bellvert, J.; Jofre-Ĉekalović, C.; Pelechá, A.; Mata, M.; Nieto, H. Feasibility of using the two-source energy balance model (TSEB) with Sentinel-2 and Sentinel-3 images to analyze the spatio-temporal variability of vine water status in a vineyard. Remote Sens. 2020, 12, 2299. [CrossRef]

259. Garrido-Rubio, J.; González-Piqueras, J.; Campos, I.; Osann, A.; González-Gómez, L.; Calera, A. Remote sensing-based soil water balance for irrigation water accounting at plot and water user association management scale. Agric. Water Manag. 2020, 238, 106236. [CrossRef]

260. Geli, H.M.E.; González-Piqueras, J.; Neale, C.M.U.; Balbontín, C.; Campos, I.; Calera, A. Effects of surface heterogeneity due to drip irrigation on scintillometer estimates of sensible, latent heat fluxes and evapotranspiration over vineyards. Water 2020, 12, 81. [CrossRef] 